\title{
Quantitative Analysis of Risk from Fragmental Rockfalls
}

2

by Jordi Corominas, Gerard Matas, Roger Ruiz-Carulla

Division of Geotechnical Engineering and Geosciences

Department of Civil and Environmental Engineering. Universitat Politècnica de CatalunyaBarcelonaTech

Jordi Girona 1-3, D-2 Building

08034 Barcelona, Spain

Ph. + 34.93.401.6861

e-mail addresses: jordi.corominas@upc.edu ; gerard.matas@upc.edu ; roger.ruiz@upc.edu

Keyworks: rockfall; fragmentation; Quantitative Risk Analysis; rockfall modelling; case study (1)

\begin{abstract}
Rockfalls are ubiquitous diffuse hazard in mountain regions, cliffs and cutslopes, with the potential of causing victims and severely damaging buildings and infrastructures. A vast majority of detached rock masses break up when impacting the ground, generating multiple trajectories of rock fragments.

In this paper, we present the quantitative risk analysis (QRA) of fragmental rockfalls. Fragmentation in rockfalls requires the redefinition of the probability of reach and the evaluation of the effect of multiple rock blocks trajectories on the exposure. An example of QRA was carried out at the Monasterio de Piedra, Spain using RockGIS, a rockfall propagation model that takes fragmentation into account (Matas et al. 2017). The results show that fragmentation has a significant but contrasting effect in the calculation of risk. The risk is reduced if the slope where blocks propagate is sufficiently long and gentle. The reason for this is that, compared to the unfragmented rock masses, the new fragments generated travel shorter distances with lesser kinetic energy. The effect disappears in case of large rockfalls. Conversely, the risk increases if the rock fragments propagate over steep slopes. The reason is that few blocks stop along the way while the generation of a cone of fragments increases the exposure. Our simulations also show that assuming a continuous flow of visitors or segregating the flow in groups of different number of people, has only a minor influence on the results. Finally, we observed that the capability of the protection barriers to stop rockfalls of up to a few tens of cubic meters increases with fragmentation.
\end{abstract}




\section{Introduction}

Rockfalls are one of the most ubiquitous diffuse hazards in mountain regions. Although the vast majority of rockfalls are local small-size events, the aggregated damage caused and the number of casualties is high (Hungr et al. 1999; Chau et al. 2003). Compared to other landslide types, rockfalls may become more damaging due to the high impact velocity of the rock blocks (Turner and Jayaprakash, 2012). Most rockfall masses fragment along their trajectory. Fragmentation consists of the separation of the initial mass into several smaller pieces, which follow independent, often divergent trajectories. It may occur just after the detachment of the rock mass from the cliff. However, it becomes more evident upon the first impact(s) on the ground surface. The blocks composing the rock mass can be either dislodged, broken or both (Ruiz-Carulla et al. 2015). Rockfalls that experience fragmentation are named fragmental rockfalls (Evans and Hungr, 1993). In this paper we refer to fragmental rockfall events of less than $5 \times 10^{4} \mathrm{~m}^{3}$, which is the size proposed as the transition from rockfalls to rock avalanches (Davies and McSaveney, 2002).

A complete rockfall study involves several aspects (Volkwein et al 2011). One is the characterization of the source and the predisposing factors (Jaboyedoff et al. 2004; Loye et al. 2009), which control the occurrence and frequency of the events. Another is the dynamics of the falling masses, which determines the trajectory, velocity, runout, and therefore, the consequences (Giani et al. 2004; Bourrier and Hungr, 2011; Asteriou et al. 2012). Rockfall simulations are strongly affected by the stochasticity of all the processes involved (Bourrier et al. 2012; Macciotta et al. 2015; Preh et al. 2015).

The analysis of rockfalls has improved significantly with the use of 3D models (Guzzetti et al. 2002; Dorren 2012; Gischig et al. 2015). These models highlight the influence of the input parameters such as the scale dependency of topographic features (Agliardi and Crosta, 2003; Lan et al. 2010; Corona et al. 2017), the resolution of the DEM (Crosta and Agliardi, 2004; Lambert, et al. 2013), and ground stiffness (Dorren et al. 2006; Wyllie, 2014), on the results. The divergence of the trajectories affect the velocities, the trajectory heights and runout of the blocks, making 3D modelling more challenging (Frattini et al. 2013; Macciota et al. 2015). Several criteria are considered for the calibration of the 3D rockfall models, which include the percentage of simulated blocks stopping close to the actual blocks; the passing frequencies through reference sections; the runout distances of the largest blocks; the passing heights of 
the blocks; among others (Stoffel et al. 2006; Agliardi et al 2009; Bourrier et al. 2009; Dorren et al. 2011; Frattini et al. 2013).

The quantitative risk analysis (hereinafter QRA) has received an increasing interest in recent years (Fell et al. 2008; Corominas et al. 2014). The objective of the QRA is to evaluate the consequences (e.g. damages, casualties) of an event and their associated probabilities. The QRA provides the objective evaluation of risk because the assumptions and uncertainties are declared (Straub and Schubert, 2008). It yields reproducible results, allowing the analysis of different scenarios, the comparison of their results, and the consideration of risk acceptability criteria.

For rockfalls, risk (R) is expressed as follows (Agliardi et al. 2009):

$$
R=\sum_{j=1}^{J} \sum_{i=1}^{I} N_{i} \cdot P(X / D)_{i} \cdot P(T / X)_{j} \cdot V_{i j}
$$

where:

$\mathrm{R}$ : risk due to the detachment from a cliff of a rock mass of magnitude (volume) "i” on an exposed element "j" located at a reference distance " $x$ " from the source.

$\mathrm{N}_{\mathrm{i}}$ : the annual frequency of rockfalls of volume class "i”".

$\mathrm{P}(\mathrm{X} \mid \mathrm{D})$ i: the probability that the detached rock mass of the size class "i” reaches a point located at a distance " $x$ ” from the source (reach probability)

$\mathrm{P}(\mathrm{T} \mid \mathrm{X})$ : the exposure or the probability that an element " $\mathrm{j}$ ” be in the trajectory of the rockfall at the distance " $x$ ", at the timing of the arrival of the rock fall debris.

$V_{\mathrm{ij}}$ : the vulnerability of an exposed element “j” being impacted by a block of magnitude “i”

The summation indicates that risk is calculated for a range of rockfall magnitudes (volumes) because each one is characterized by its probability of occurrence and runout. Therefore, the consequences vary for each range of rockfall volumes.

Compared to the fall of intact blocks, fragmentation causes the redistribution of the initial mass between the new generated fragments. To the authors' knowledge, no attempt has been made so far to calculate 93 
$\mathrm{P}(\mathrm{X} \mid \mathrm{D})$ or the reach probability for unfragmented rockfalls is calculated with numerical models that simulate hundreds or thousands of trajectories. In the analysis of linear features (roads, trails), the probability of reach, for each rockfall magnitude, is given by the percentage of all simulated blocks that cross a reference section (Guzzetti et al., 2002; Jaboyedoff and Labiouse, 2011). However, if the rock mass is fragmented, this procedure may yield probabilities $>1$. The reason is that the number of newly generated fragments that reach the section, can be bigger than the number of initiators. To overcome this

restriction, here $\mathrm{P}(\mathrm{X} \mid \mathrm{D})$ is obtained as the proportion of the simulations that reach the analyzed section, regardless whether they consist of one or more fragments. However, the number of fragments reaching the section, is considered in the calculation of the exposure.

The procedure for evaluating P (T | X) in linear features is known (Roberds, 2005; Ferlisi et al. 2012; Macciotta et al. 2016). The probability of impact on any exposed element that moves along the analyzed section at the instant of arrival of the rockfall blocks, is function of the flow of elements and the width of the rockfall. For people moving along a trail path is (adapted from Nicolet et al., 2016):

$$
P(T / X)=\frac{f_{p} \cdot\left(w_{r}+l_{p}\right)}{24.1000 \cdot v_{p}}
$$

where:

\section{$\mathrm{f}_{\mathrm{p}}$ : people flow (persons/day)}

$\mathrm{W}_{\mathrm{r}}$ : width of the rockfall debris front (m)

$l_{\mathrm{p}}$ : length of the trail occupied by the person or group of people (m)

$\mathrm{v}_{\mathrm{p}}$ : is the mean velocity of the person or group of people $(\mathrm{km} / \mathrm{h})$

$\mathrm{W}_{\mathrm{r}}$ is the actual width occupied by the rockfall or the length of the trail actually affected by the event (Nicolet et al. 2016). This is true if the rockfall forms a continuous front as occurs in mudslides, snow avalanches, or debris flows. Rock fragments in fragmental rockfalls often follow divergent trajectories that can be simplified as forming a cone (Figure 1). In plan view, the affected area is defined by the projected cone of fragments. The width of the cone $\left(w_{c x}\right)$ varies (e.g. increases) with the distance travelled downslope (x). The rockfall deposit may form a continuous debris mantle (light brown polygon in figure 1) or consists of scattered blocks over the slope. 


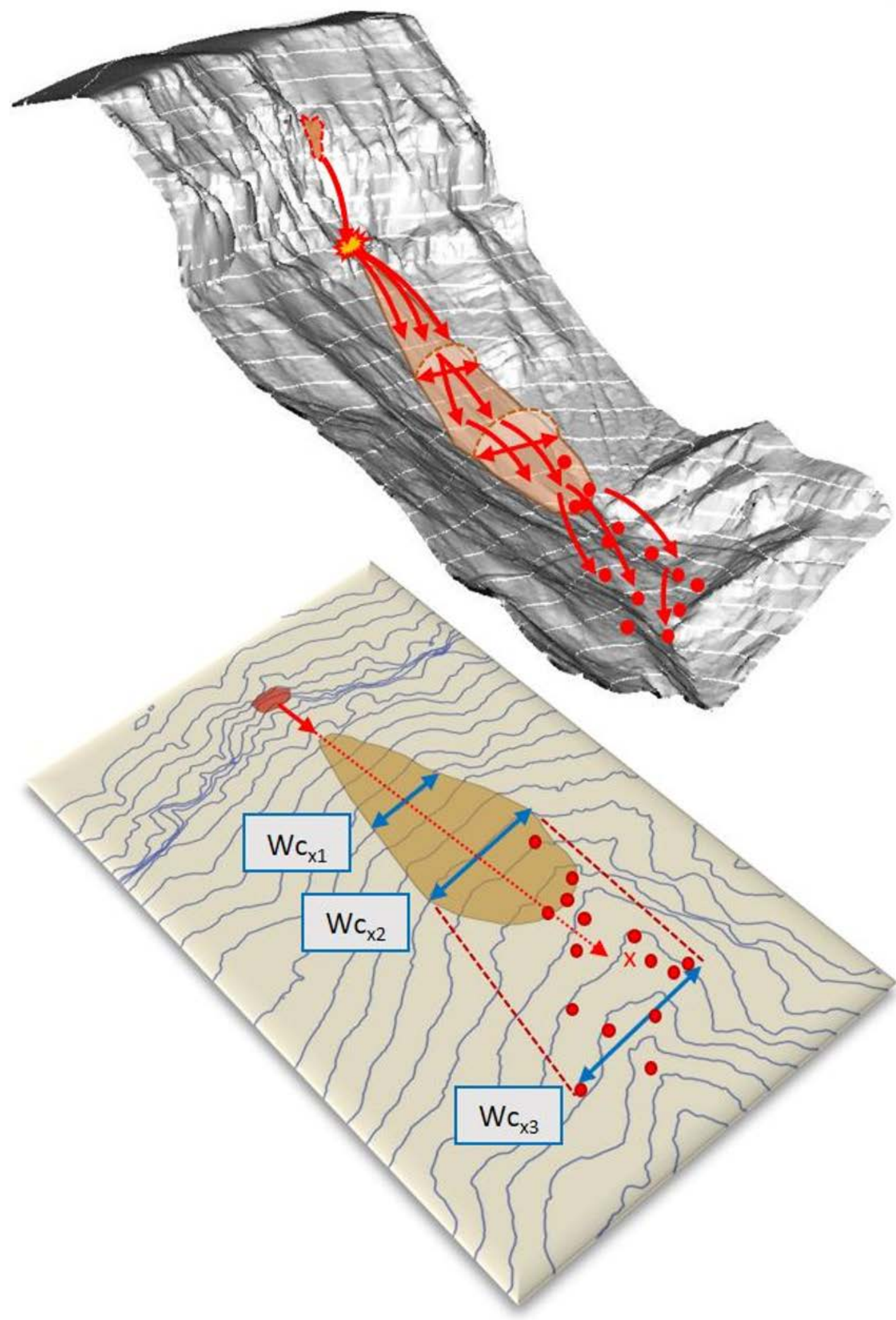

124 Figure 1. Sketch of the fragmentation of a rockfall mass upon impact with the ground surface. The 125 projected width $(W c)$ of the cone of fragments generated varies with the distance $(x)$ from the rockfall 126 source. $W c_{x 1}$ and $W c_{x 2}$ are the width of the continuous debris mantle (light brown polygon) at the 127 distances $x_{1}$ and $x_{2} . W c_{x 3}$ is the width of the cone containing the scattered rock block fragments, at a 128 distance $x_{3}$. 
Therefore, to obtain $\mathrm{Wr}, \mathrm{W}_{\mathrm{cx}}$ must be calculated first at each analyzed section. In case of rockfall events forming a continuous debris cover at the analyzed section, then $\mathrm{W}_{\mathrm{r}}=\mathrm{W}_{\mathrm{cx}}\left(\mathrm{Wc}_{\mathrm{x} 1}\right.$ and $\mathrm{Wc}_{\mathrm{x} 2}$ in figure 2). However, in case of scattered blocks ( $\mathrm{Wc}_{\mathrm{x} 3}$ in figure 2), $\mathrm{W}_{\mathrm{r}}$ is calculated considering the fraction of the cone width actually occupied by the blocks. To the sole effect of estimating $\mathrm{W}_{\mathrm{r}}$ in equation [2], here we assume that all the rock fragments reaching the analyzed section located at a distance " $\mathrm{x}$ " from the source, are equally sized to the modal block size $\left(\mathrm{W}_{\mathrm{mx}}\right)$. The number of blocks reaching the analyzed section are counted in each simulation. Thus, the rockfall width Wr is:

$\mathrm{W}_{\mathrm{r}}=\mathrm{n} . \mathrm{W}_{\mathrm{mx}}$

Where " $n$ " is the number of blocks reaching the section (at a distance " $x$ ")

If $\mathrm{n} \cdot \mathrm{W}_{\mathrm{m}} \geq \mathrm{W}_{\mathrm{cx}}$, then $\mathrm{W}_{\mathrm{r}}=\mathrm{W}_{\mathrm{cx}}$

Where $W_{c x}$ is the width of the cone of trajectories at a distance " $x$ " from the source

In this paper, we analyze how rockfall fragmentation affects the QRA. To this purpose, we present the example of the Monasterio de Piedra, Spain. Although the risk will be quantified, the main goal is to illustrate the effect of fragmentation on the risk values and the interpretation of the results.

\section{The site: Monasterio de Piedra trails}

The Monasterio de Piedra is a protected natural space that receives more than 250,000 visitors every year. It is located in the lower reach of the River Piedra, in the central Iberian Range, NE Spain, a NWSE trending alpine intraplate fold belt (Figure 2). The climate is of a continental Mediterranean type with strong seasonal contrasts. The mean annual precipitation is around $400 \mathrm{~mm}$. The geological setting corresponds to a series of Mesozoic carbonate rocks, Miocene detrital formations and Quaternary tufa (Arenas et al. 2014). The River Piedra incised and down cut the carbonate formation during the Quaternary forming a number of small gorges and canyons, in which thick Pleistocene and Holocene tufa deposits were generated (Osácar et al. 2013). One of these gorges extends around the Lago del Espejo (Mirror lake), whose 100m-high cliffs are composed of a sequence of dolostones and limestones of Upper Cretaceous age. At the base of the cliffs predominate finely stratified limestone (30 to $50 \mathrm{~cm}$ thick layers) while in the upper part the strata are massive white limestones (Figure 3). In addition to the stratification, which displays different dip angle at both sides of the lake, the rock mass is crossed by 
164 that left karstic features easily identifiable in the outcrops.

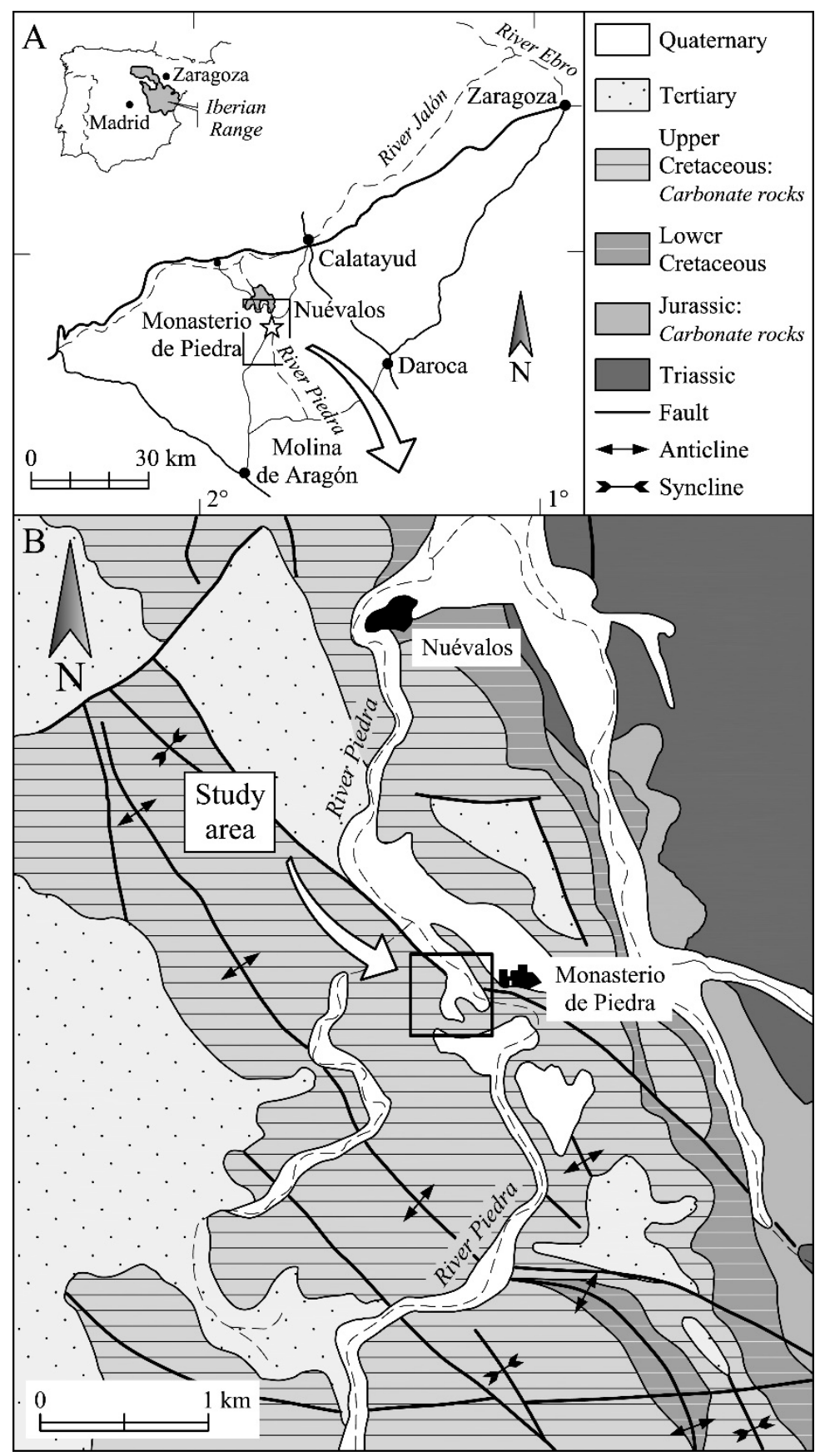

166 Figure 2. (top) Site location and (bottom) geological map of the Monasterio de Piedra area (modified 167 from Osácar et al. 2013) 


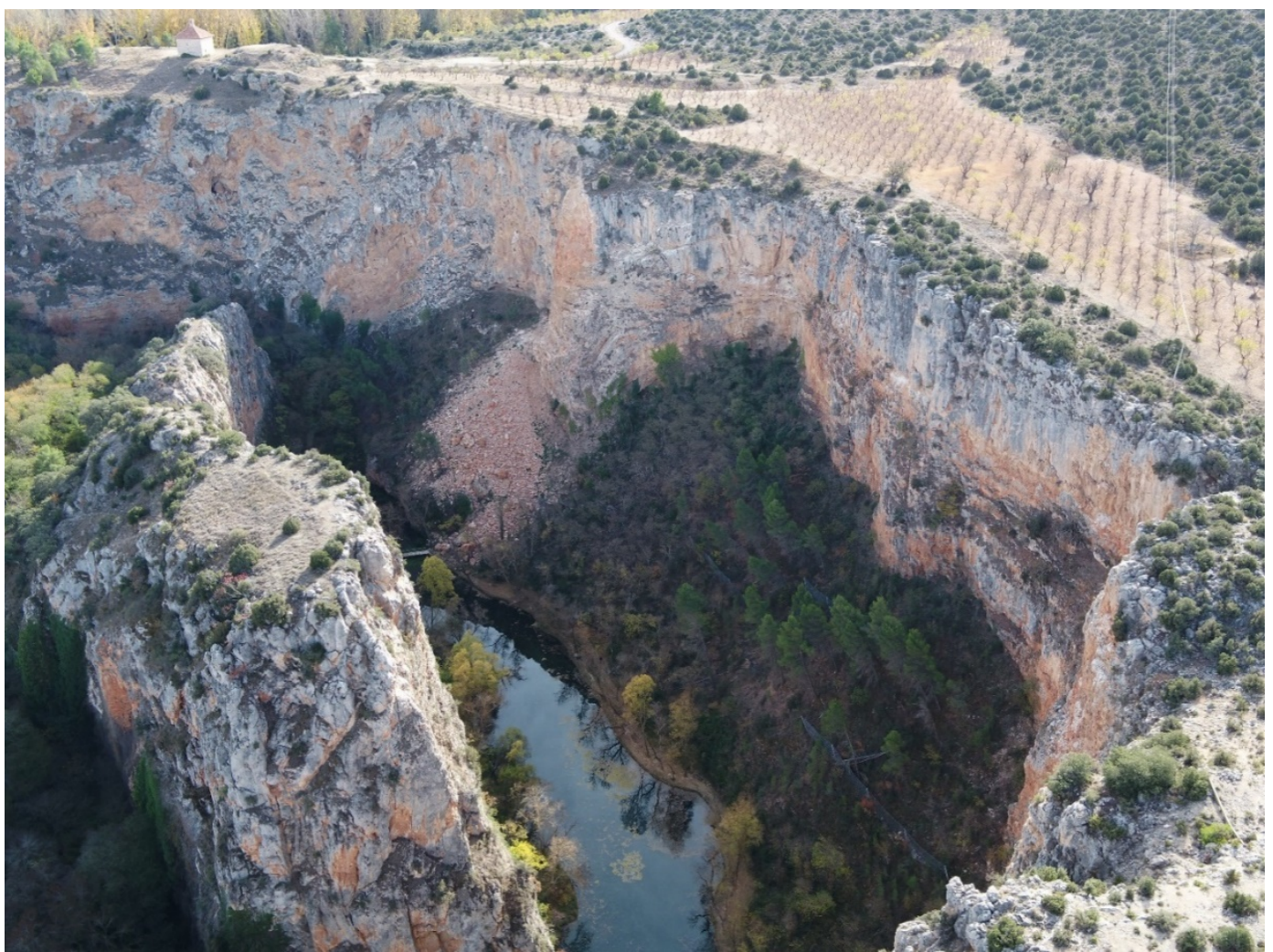

Figure 3. View from the North of the limestone cliffs around the Lago del Espejo (Mirror lake) and the trail at Monasterio de Piedra. At the foot of the cliff, in the background, the rockfall debris of February 2017. On the lower right gentle slope, between the trees, several rockfall barriers have been installed. On the left, the steep cliff of Peña del Diablo (Devil's rock)


Figure 4. Modal poles of the discontinuity sets present at the cliffs (SE and NE) around the Lago del Espejo. The poles that satisfy the conditions of kinematic instability for a friction angle of 30\% are indicated. The cliff faces and bedding planes (E1 and E2) are represented by purple and green color great circles, respectively. 
181 The limestone and dolostone rocks outcropping at the Piedra river gorge are highly resistant materials that 182 form vertical slopes of more than a hundred meters high. In the Monasterio de Piedra, the stability is 183 controlled by the presence of discontinuities (stratification, joints, and faults) since they facilitate the 184 individualization of the rock blocks although the failure mechanism is complex. Despite the fact that the 185 criterion of kinematic instability (Hoek and Bray, 1981) is satisfied for some joint sets (Figure 4), the failure 186 is often prevented by the presence of rock bridges. Failure of the rock columns may also be generated by 187 rock deterioration and rock slaking processes. More than 40 large $\left(>5 \mathrm{~m}^{3}\right)$ potentially unstable rock masses 188 on the cliffs around the lake were identified with a camera mounted on an Unmanned Aerial Vehicle 189 (UAV). They consist of rock columns partially detached from the cliff. The columns show distinct 190 perimetral cracks, and often rest on planes daylighting at the cliff face and dipping towards the lake.

191 On February $17^{\text {th }}, 2017$ a rock mass of about $800 \mathrm{~m}^{3}$ detached from the cliff above the Lago del Espejo 192 (Figure 3). The mass fell from a height of 60m and fragmented upon impacting on the ground. The debris 193 extended downslope to the lake, burying a section of the visitors trail. Several modules of the rockfall 194 barrier of $1500 \mathrm{~kJ}$, located just below the cliff, were destroyed. Previously, in October 1986 another rockfall 195 event of a volume of about $600 \mathrm{~m}^{3}$ occurred, generating a young debris cover of $500 \mathrm{~m}^{2}$ approximately. Its 196 source is located close to that of the 2017 event.

\section{Materials and Methods}

199 We have carried out the QRA at the Lago del Espejo, based on the equation [1] and considering two 200 scenarios (with and without rockfall fences). Two alternative trails located at a variable distance " $\mathrm{x}$ " from 201 the cliffs are analyzed (Figure 5). One trail runs along the SW margin of the lake, separated from cliff by 202 a gentle slope and the other on the NE margin, just under the Peña del Diablo. For the sake of brevity, the analysis of only one section per trail is presented here. 


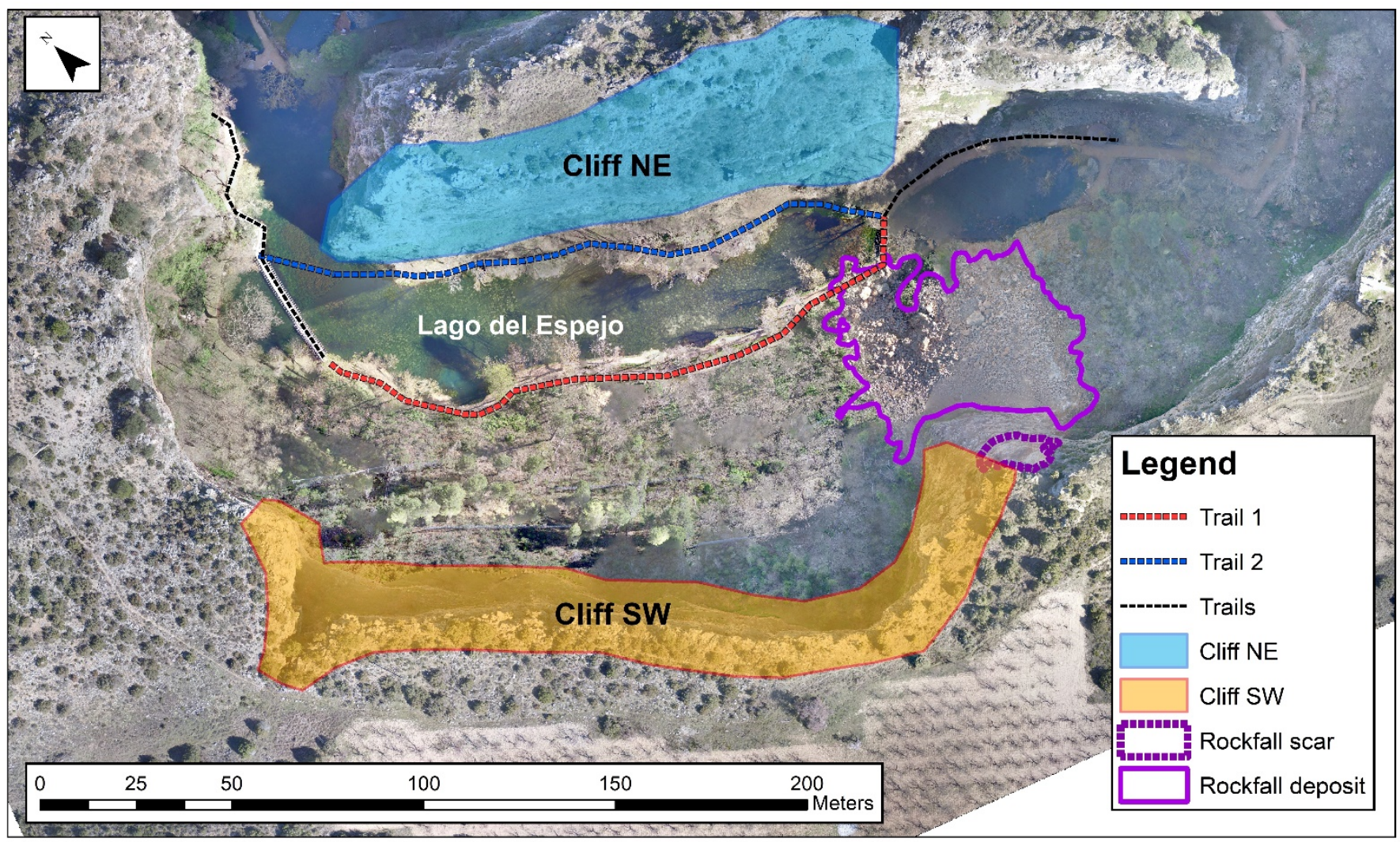

Figure 5. Orthoimage of the two trail sections analyzed (red and blue lines) and their contributing cliffs. The location of the rockfall event of February 2017 is also shown (purple line).

To perform the analysis of risk a high-resolution digital elevation model (DEM) was prepared using the digital images captured with a drone. The resolution of the DEM achieved is $0.2 \times 0.2 \mathrm{~m}$

\section{$\underline{\text { Scenarios analyzed and assumptions }}$}

Trail section 1 is affected by rockfalls originated from the SW cliff (Figure 5). Below the cliff, five flexible rockfall fences of $1500 \mathrm{~kJ}$ capacity built in 2002, are located. One of them was destroyed by the event of 2017. Trail section 2 is affected by rockfalls originated from the NE cliff (known as Peña del Diablo). Two scenarios are analyzed: (1) the original situation; (2) presence of the $1500 \mathrm{~kJ}$-capacity barriers (for trail 1 only)

Rockfall sources are uniformly distributed along the crest line of the cliffs (one every meter), and their occurrence is independent of the flow of visitors (Hantz, 2011). This hypothesis accommodates well to the large-size potentially detachable rock masses identified but it is conservative for mid-size rockfalls (up to $50 \mathrm{~m}^{3}$ ) because a percentage of them originates in middle and lower sectors of the cliff face. Failures from the mid-lowest cliff sectors will produce smaller kinetic energies and runout. 
This case study aims at calculating the risk associated to the direct impact of rockfalls on visitors walking around the lake. Other circumstances such as people stopping for a while on the trail (for instance, working, resting, picnicking or camping) or wandering out of the limits of the trail, are beyond the scope of this analysis.

In what follows, we present how the different components of the equation 1 are determined

\section{$227 \quad$ Frequency of the rockfall events (Ni)}

The average frequency of rockfalls is obtained from the inventory of events as done in other case studies (Bunce et al. 1997; Hungr et al. 1999; Guzzetti et al. 2004; Ferlisi et al. 2012). We prepared the magnitude-frequency relation of rockfall events at the site, using two sources: (i) the count of rock blocks intercepted by the barriers installed 15 years ago (in 2002), and (ii) the inventory of three large events (>400 $\mathrm{m}^{3}$ ), two historical (1986 and 2017) and the third of unknown age. A total of 209 rock blocks were measured in four barriers. The volume distribution of the blocks covers three orders of magnitude and it fits to a potential law (Figure 6).

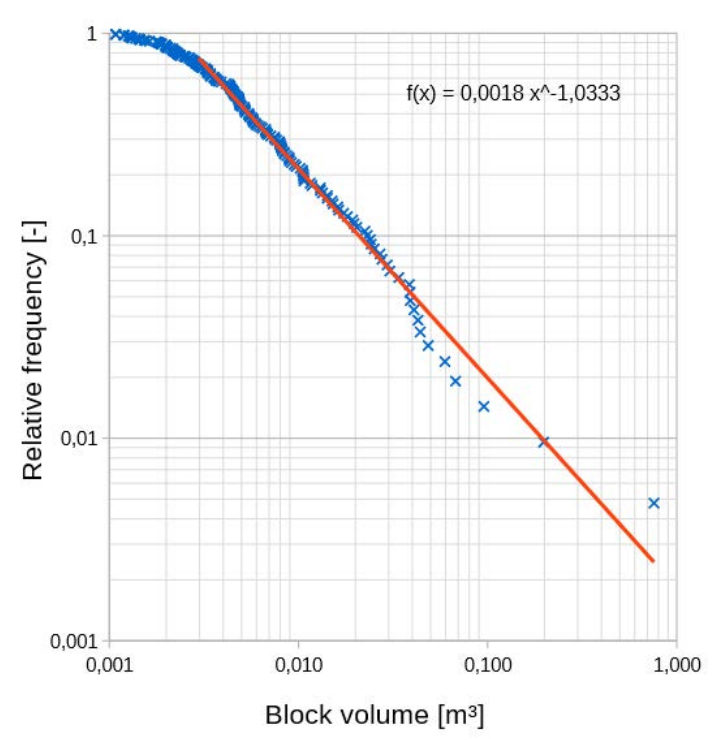

237 Figure 6. Volume distribution of the rock blocks retained in the four rockfall fences

The rockfall rate obtained in the barriers is 14 events / year. This value is only an approximate estimation of the frequency because some small-size blocks did not reach the fences (a small percentage) while some of the blocks retained could be part of the same fragmental rockfall event, thus underestimating its size. As the fences collect the rockfalls originated within the cliff SW only, the frequency-magnitude (F- 
M) relation has been extrapolated to the whole cliff length around the Lago del Espejo. In addition, the three large rockfalls inventoried were also included. The extrapolated frequency and the volumetric distribution of the events (arranged in bins) are presented in Table 1.The total rock fall debris volume accumulated in 1000 years is about 4,200 $\mathrm{m}^{3}$. The denudation rate of the cliffs considering their exposed surface of 55,260 $\mathrm{m}^{2}$ (921 $\mathrm{m}$ in length and $60 \mathrm{~m}$ in height), is $76 \mathrm{~mm} / \mathrm{ka}$. This rate is of the same order of magnitude as the observed within the region (Sancho et al., 1988; Gutiérrez et al., 2001). Based on this, we consider the F-M relation obtained as acceptable to our purposes. Finally, the frequency assigned to each trail section is proportional to the length of the contributing cliff.

\begin{tabular}{|c|c|c|c|c|c|}
\hline $\begin{array}{c}\text { Volume } \\
\text { class }\end{array}$ & $\begin{array}{c}\text { Rockfall volume } \\
\left(\mathrm{m}^{3}\right)\end{array}$ & Events/yr & $\begin{array}{c}\text { Annual volume } \\
\mathrm{m}^{3} / \mathrm{yr}\end{array}$ & $\begin{array}{c}\text { Volume }\left(\mathrm{m}^{3}\right) \\
\text { per ka }\end{array}$ & $\begin{array}{c}\text { Cumulative volume } \\
\left(\mathrm{m}^{3}\right) \text { in } 1 \mathrm{ka}\end{array}$ \\
\hline $\mathrm{A}$ & $\leq 0.005$ & 45.1463 & 0.226 & 226 & 226 \\
\cline { 2 - 6 } & $0.005<\mathrm{x} \leq 0.05$ & 5.9514 & 0.298 & 298 & 523 \\
\hline $\mathrm{B}$ & $0.05<\mathrm{x} \leq 0.5$ & 0.7846 & 0.392 & 392 & 916 \\
\hline $\mathrm{C}$ & $0.5<\mathrm{x} \leq 5$ & 0.1034 & 0.517 & 517 & 1433 \\
\hline $\mathrm{D}$ & $5<\mathrm{x} \leq 50$ & 0.0136 & 0.682 & 682 & 2114 \\
\hline $\mathrm{E}$ & $50<\mathrm{x} \leq 500$ & 0.0018 & 0.899 & 899 & 3013 \\
\hline $\mathrm{F}$ & $500<\mathrm{x}$ & 0.0002 & 1.185 & 1185 & 4198 \\
\hline
\end{tabular}

Table 1. Frequency of rockfall events by the extrapolation of the volumes retained in the barriers and of the three major events identified along the $921 \mathrm{~m}$ length of the cliffs.

\section{Probability of reach $\mathrm{P}(\mathrm{X} \mid \mathrm{D})_{\mathrm{i}}$}

To calculate $\mathrm{P}(\mathrm{X} \mid \mathrm{D}) \mathrm{i}$, the probability of the rockfall event reaching the trail section, we used the code RockGIS developed by our research group (Matas et al. 2017). It is a GIS-Based model that simulates stochastically the fragmentation of rockfalls. The input data are the digital surface model, the land use map, the rockfall sources and their volumes. The code simulates the propagation of the blocks based on a lumped mass approach. It calculates the rebound of the rock blocks using restitution factors according to the land cover. In RockGIS, the fragmentation initiates by the disaggregation of the detached rock mass, composed of blocks delimited by the pre-existing discontinuities which can be characterized by the In-situ Block Size Distribution (IBSD). An energy threshold is defined in order to determine whether the rock blocks break or not at each impact upon the ground surface. The distribution of the initial mass among the newly generated rock fragments is carried out stochastically, following a power law. To this purpose, we use the fractal fragmentation model of Ruiz-Carulla et al. (2017). The remaining energy after the impact is distributed proportionally to the mass of each new fragment. All the fragments generated propagate downslope within a cone of trajectories and the process continues iteratively until all fragments stop. The model is calibrated considering the position and volume of the largest blocks 
generated, the total amount of blocks, their volume distribution and the runout distances (Matas et al. 271 2017).

The parameters of the model are calibrated with the rockfall event of February 2017; the location of several blocks (volume ranging between 0.5 and $5 \mathrm{~m}^{3}$ ) removed from the cliff during scaling works carried out in March 2015; and the blocks retained at the rockfall barriers. The in-situ block size distribution (IBSD) of the rockfall event of 2017 is obtained from the images captured with a drone. First, the rockfall volume is calculated comparing the 3D digital surface models before and after the rockfall event. A Discrete Fracture Network model is used to simulate the discontinuity pattern of the detached rock mass and to generate the IBSD. The rockfall block size distribution (RBSD) is measured in the field and modelled, following the approach of Ruiz-Carulla et al. (2015). All the largest blocks (> $1 \mathrm{~m}^{3}$ ) were measured with a tape. We used two sampling plots to measure the size distribution of the smallest blocks $\left(<1 \mathrm{~m}^{3}\right)$ and the results were extrapolated to the whole debris cover. The block size distribution obtained fits well to a power law. The total volume of the rockfall fragments has been checked against the volume at the rockfall source. Figure 7 and Figure 8 show the results of the simulation of the 2017 event, the ISBD and both the measured and simulated RBSD. The spatial distribution of rock fragments on the slope and the runout distances are checked using the procedure described in Matas et al. (2017). 


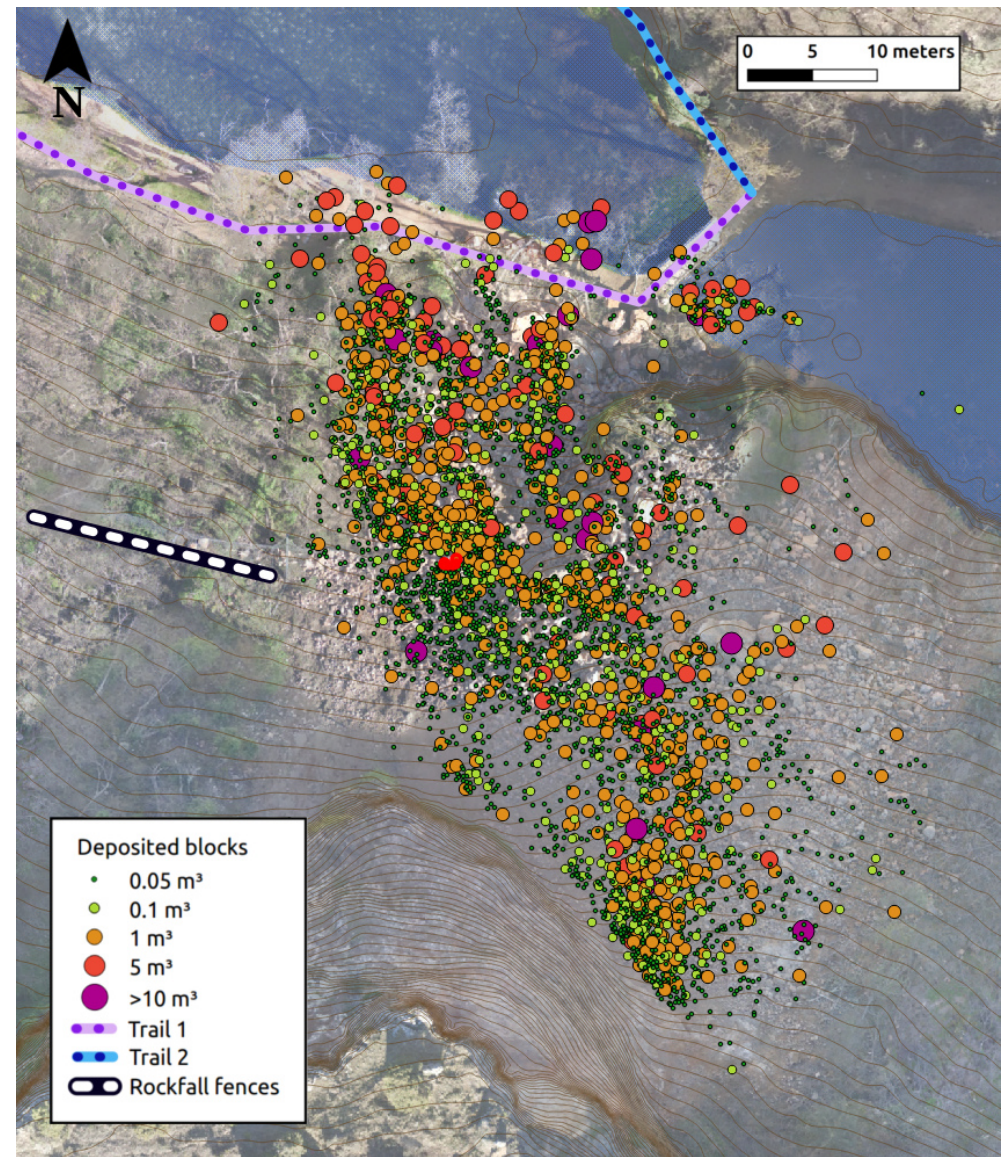

289 Figure 7. Calibration of the rockfall event of February 2017. The simulated blocks are overlaid on the 290 orthophoto showing the actual distribution of the blocks. The volume of the rock blocks is indicated by the 291 size and color of the circles.

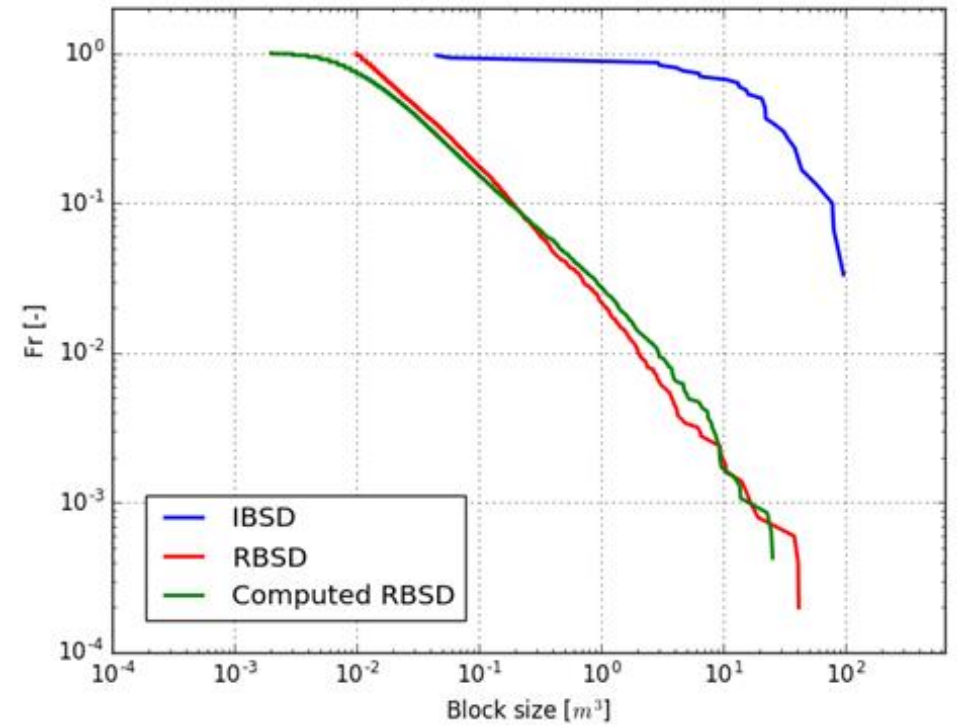

293 Figure 8. In situ block size distribution (IBSD) of the rock mass failure in February 2017 and both the 294 computed and measured rock block size distribution (RBSD) of the fragments. 
296 The rockfall sources are distributed homogeneously every 1m (294 and 132 potential rockfall sources, 297 for the cliff above the trail sections 1 and 2, respectively). Each source releases 100 rock masses that 298 remain unbroken along the path and 10 rock masses that fragment, totaling 29,400 and 2,940 simulations $299 \quad$ respectively for trail 1 and 13200 and 1320 for trail section 2.

300 The effect of fragmentation on the rockfall runout is illustrated in Figure 9. For the sake of visualization 301 only one trajectory per intact rockfall from a few selected detachment sources is shown (top). Similarly, 302 only one fragmental rockfall event is shown (bottom). In the latter, the trajectories of the rock fragments 303 are also displayed. It is important to note that the divergence of the trajectories increases the length of 304 the section trail affected and, consequently, the probability of impact. 

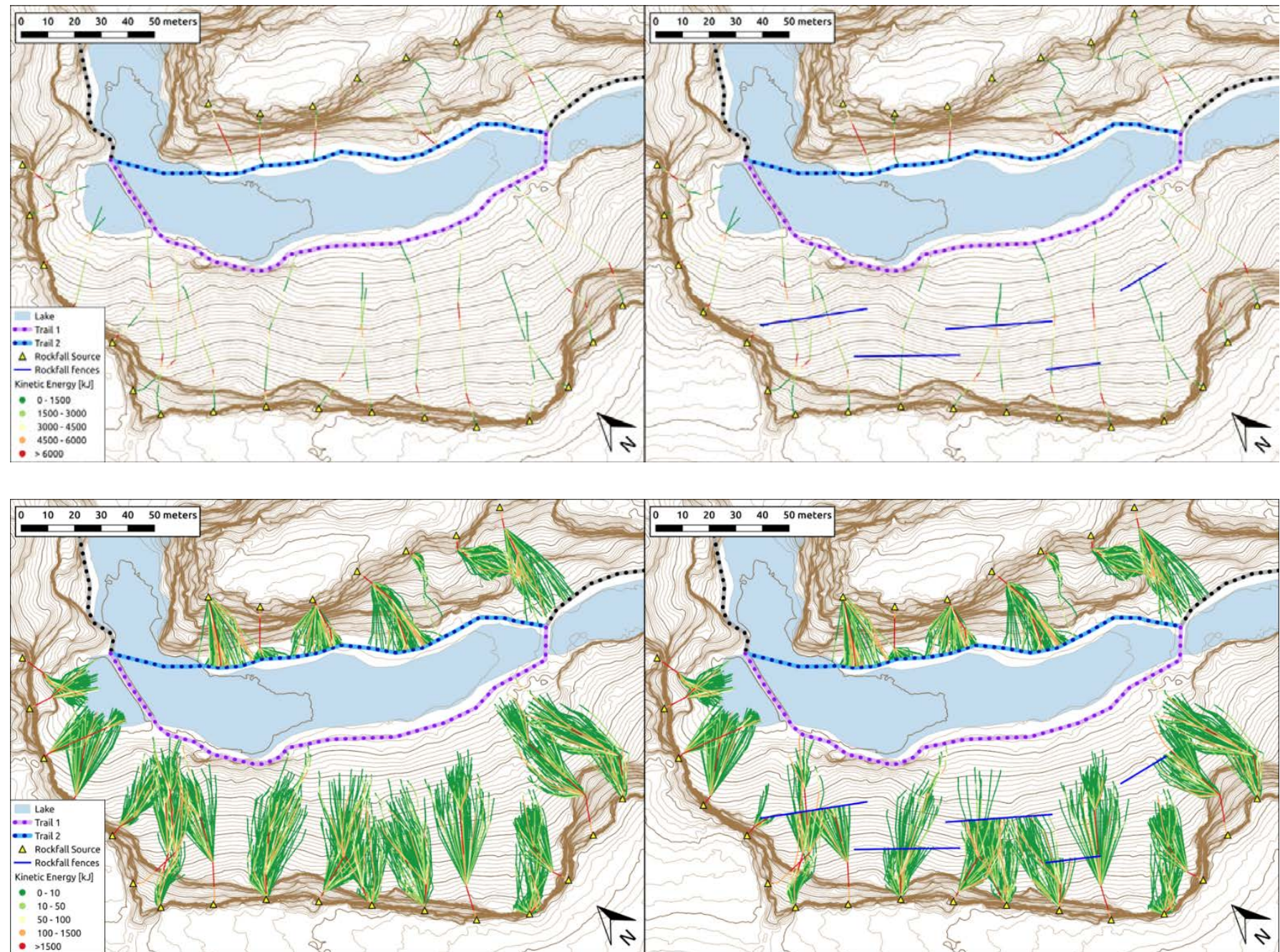

309

Figure 9. Top: trajectories of unfragmented rockfall masses of $10 \mathrm{~m}^{3}$. Considering the presence (right) or absence of rockfall barriers; Bottom: trajectories of $10 \mathrm{~m}^{3}$ fragmental rockfall. Considering the presence (right) or absence of rockfall barriers (blue lines). The kinetic energies are displayed following a color code (from high to low: red orange, yellow and green).

The results shown in Table 2 illustrate that runout is strongly affected by both the size of the event and by the fragmentation. For unfragmented rockfalls, only $12 \%$ of the modelled smallest rockfalls $\left(<0.05 \mathrm{~m}^{3}\right)$ reach the trail section 1 compared to the $87 \%$ in case of occurrence of the largest events $\left(>500 \mathrm{~m}^{3}\right)$. For fragmental rockfalls, reaching the trail means that at least one block fragment has arrived. The results of Figure 9 and Table 2 show that fragmentation reduces propagation significantly if the slope is sufficiently gentle and long. None of the simulated rockfall events smaller than $0.5 \mathrm{~m}^{3}$ reaches the trail section 1. However, the shortening of the runout disappears progressively with the increase of the rockfall size. In fact, the reduction of the distance travelled for volumes larger than $50 \mathrm{~m}^{3}$ is barely perceptible. 


\begin{tabular}{|l|l|l|l|l|l|c|}
\hline & \multicolumn{4}{|c|}{ Trail Section 1 } & \multicolumn{2}{c|}{ Trail Section 2 } \\
\hline \multirow{2}{*}{$\begin{array}{l}\text { Rockfall } \\
\text { volume }\left(\mathrm{m}^{3}\right)\end{array}$} & \multicolumn{2}{|c|}{ Natural state } & \multicolumn{2}{c|}{ Flexible fences 1500kJ } & \multicolumn{2}{c|}{ Natural state } \\
\cline { 2 - 7 } & $\mathrm{U}$ & $\mathrm{F}$ & $\mathrm{U}$ & $\mathrm{F}$ & $\mathrm{U}$ & $\mathrm{F}$ \\
\hline$<0.05$ & 0.1194 & 0 & 0.0220 & 0 & 0.6105 & 0.2940 \\
\hline $0.05<\mathrm{x}<0.5$ & 0.3280 & 0 & 0.0647 & 0 & 0.8394 & 0.5700 \\
\hline $0.5<\mathrm{x}<5$ & 0.5896 & 0.0425 & 0.1455 & 0.0124 & 0.9446 & 0.7910 \\
\hline $5<\mathrm{x}<50$ & 0.7647 & 0.2327 & 0.7361 & 0.1310 & 0.9699 & 0.9515 \\
\hline $50<\mathrm{x}<500$ & 0.8320 & 0.6309 & 0.8312 & 0.5135 & 0.9792 & 0.9886 \\
\hline$>500$ & 0.8735 & 0.7996 & 0.8735 & 0.7574 & 0.9820 & 0.9917 \\
\hline
\end{tabular}

Table 2. Proportion of rockfall trajectories $P(X \mid D)$ reaching the trail sections for both unfragmented (U) and fragmental $(\mathrm{F})$ rockfalls.

On the other hand, on trail section 2 that runs under the steep slope of the Peña del Diablo, the fragmentation has a lesser influence on the distance traveled by the blocks. The percentage of rockfall events that stop along the path due to fragmentation is only noticeable for volumes smaller than $5 \mathrm{~m}^{3}$ and despite this, a significant number of events reach the trail. The path is too steep for the small blocks to stop. For the largest events $\left(>50 \mathrm{~m}^{3}\right)$, the breakage of the falling rock mass generates tens or hundreds of fragments and the probability that at least one of them reaches the trail, increases.

The RockGIS code allows counting the number of blocks reaching the section. This information is used to calculate the exposure as shown next.

\section{Exposure P $(\mathrm{T} \mid \mathrm{X})_{\mathrm{i}}$}

The probability of the rockfall hitting visitors at a distance " $\mathrm{x}$ " from the source (equation 2), takes into account both the probability that the person or group of people is located within the rockfall trajectory and the width of the trail section intersected by the cone of rock fragments $\left(\mathrm{W}_{\mathrm{r}}\right)$. For unfragmented rockfalls, $\mathrm{W}_{\mathrm{r}}$ is the width of the fallen rock block assuming a cubic shape. For fragmental rockfalls, $\mathrm{W}_{\mathrm{r}}$ is the fraction of the cone of fragments width $\mathrm{W}_{\mathrm{cx}}$, actually containing rock fragments, calculated with the information provided by the RockGIS code

In the study area, the width of the cone of block fragments $\left(\mathrm{W}_{\mathrm{cx}}\right)$ increases with the distance $(\mathrm{x})$ from the source and with the number of impacts (Figure 9). Compared to unbroken rock blocks, the length of the trail section intersected by the rock fragments trajectories $\left(\mathrm{W}_{\mathrm{cx}}\right)$ increases up to an order of magnitude (Table 3). This has a direct effect on the exposure. 


\begin{tabular}{|l|c|c|c|c|}
\hline \multirow{2}{*}{ Rockfall volume $\left(\mathrm{m}^{3}\right)$} & \multicolumn{2}{|c|}{ Trail section 1 } & \multicolumn{2}{c|}{ Trail section 2 } \\
\cline { 2 - 5 } & unfragmented & fragmental & unfragmented & fragmental \\
\hline$<0.05$ & 0.2 & None reaching & 0.2 & 6 \\
\hline $0.05<\mathrm{x}<0.5$ & 0.8 & None reaching & 0.8 & 9 \\
\hline $0.5<\mathrm{x}<5$ & 1.5 & 17.5 & 1.5 & 13 \\
\hline $5<\mathrm{x}<50$ & 3.5 & 20 & 3.5 & 18 \\
\hline $50<\mathrm{x}<500$ & 8 & 40 & 8 & 25 \\
\hline$>500$ & 10 & 55 & 10 & 32 \\
\hline
\end{tabular}

Table 3. Wcx values for different unfragmented and fragmental rockfall volumes, calculated with the

To calculate $W_{\mathrm{r}}$ using equation 3 , both the modal size and number " $n$ " of fragments reaching the analyzed section simulated by the RockGIS code are used. An example is shown in Figure 10 and Table

4. The block fragments have a modal witdh $\left(\mathrm{W}_{\mathrm{m}}\right)$ of $1 \mathrm{~m}$ and the length of the trail intersected by the cone of fragments is $W_{c x}=20 \mathrm{~m}$. In the example, only $21 \%$ of the trajectories (reach probability $=1-0.79$ ) of the simulated fragmental rockfall events, reach the trail. The percentage of trajectories with one or more rock fragments simultaneously reaching the trail and the $\mathrm{W}_{\mathrm{r}}$ calculated with the equation 3, are included in Table 4. In the example, $8.5 \%$ of the simulated trajectories involve up to two fragments reach the trail. Considering the modal width, they occupy $2 \mathrm{~m}$, which is $10 \%$ of the $\mathrm{W}_{\mathrm{cx}}$.

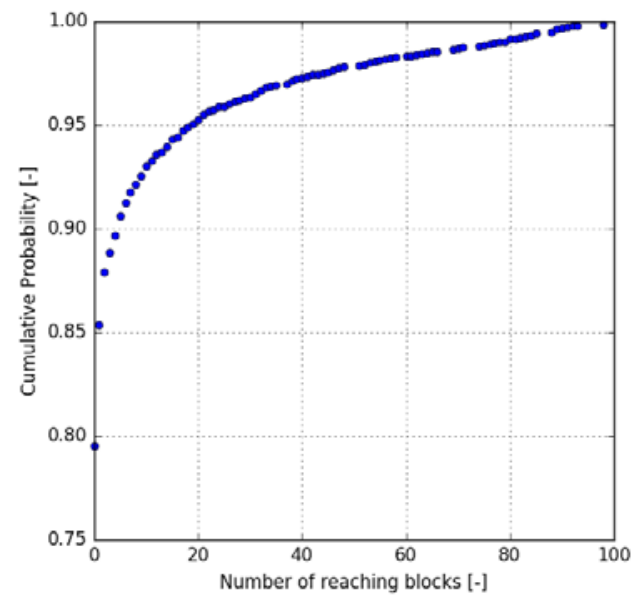

Figure 10 Cumulative probability of the simulated trajectories for each number of reaching fragments, 


\begin{tabular}{|c|c|c|c|c|}
\hline $\begin{array}{c}\text { \% of simulated } \\
\text { trajectories }\end{array}$ & $\begin{array}{c}\text { \# of blocks } \\
\text { reaching the trail }\end{array}$ & $\mathrm{P}(\mathrm{X} \mid \mathrm{D})$ & $\begin{array}{c}\text { Proportion of } \\
\mathrm{w}_{\mathrm{cx}}\end{array}$ & $\begin{array}{c}\mathrm{W}_{\mathrm{r}} \text { calculated } \\
(\mathrm{m})\end{array}$ \\
\hline 79 & none & 0 & 0 & 0 \\
\hline 8.5 & $1-2$ & 0.085 & 0.1 & 2 \\
\hline 2 & $3-4$ & 0.02 & 0.2 & 4 \\
\hline 2 & $5-6$ & 0.02 & 0.3 & 6 \\
\hline 1.5 & $7-8$ & 0.01 & 0.4 & 10 \\
\hline 1 & $9-10$ & 0.01 & 0.5 & 12 \\
\hline 1 & $10-12$ & 0.01 & 0.6 & 14 \\
\hline 0.5 & $13-14$ & 0.005 & 0.7 & 18 \\
\hline 0.5 & $15-16$ & 0.005 & 0.8 & 20 \\
\hline 0.25 & $17-18$ & 0.0025 & 0.9 & 1 \\
\hline 4.25 & 19 or more & 0.0425 & 0.9 & 16 \\
\hline
\end{tabular}

Table 4.Value of Wr and its associated probability for the case example of a fragmental rockfall considering the reach probability for one or more blocks of Figure 10. In the example, the block fragments have a modal witdh (Wm) of $1 \mathrm{~m}$ while the length of the trail intersected by the cone of fragments is $W c x=20 \mathrm{~m}$.

This procedure for estimating Wr in fragmental rockfall events is repeated for each rockfall size and for each analyzed trail section.

The exposure, $\mathrm{P}(\mathrm{T} \mid \mathrm{X})$ also requires considering the flow of visitors $\left(\mathrm{f}_{\mathrm{p}}\right)$. During the last 16 years, the Monasterio de Piedra natural site has received an average number of 250,040 visitors per year $(696 \approx$ 700 visitors/day). Most QRA studies for infrastructures such as roads and railways, assume uniformly distributed flow of the exposed elements in space (all of them occupy the same length) and time (Hungr et al. 1999; Ferlisi et al. 2012; Michoud et al. 2012; Nicolet et al. 2016; Macciotta et al. 2016). This assumption is arguable in the case of Lago del Espejo as the visitors usually walk in groups of different sizes. For this reason, we have carried out two calculations: (a) Uniformly distributed flow of visitors; (b) Flow of visitors distributed in groups as follows: $10 \%$ individuals, $45 \%$ in couples, 35\% in groups of 4 people, $10 \%$ in groups of 10 people (Table 5).

\begin{tabular}{|l|l|l|l|l|}
\hline \multicolumn{6}{|l|}{ Distribution of the daily visitors flow ( $~ 700$ visitors) in groups } \\
\hline type & individuals & Groups of 2 & Groups of 4 & Groups of 10 \\
\hline percentage & $10 \%$ & $45 \%$ & $35 \%$ & $10 \%$ \\
\hline \# of people & 70 & 313 & 243 & 70 \\
\hline \# of sets & 70 & 157 & 61 & 7 \\
\hline
\end{tabular}

Table 5. Distribution of the visitors' flow in the Lago del Espejo, used in the QRA 
382 In equation 2, all the visitors whether they are individuals or groups of any size, move at an average speed $\left(v_{p}\right)$ of $2 \mathrm{~km} / \mathrm{h}$. The width or length of the person $\left(l_{p}\right)$ is assumed $0.5 \mathrm{~m}$ as suggested by Hantz (2011).

$\underline{\text { Consequences }}$

386 Several reported incidents in the media show that a percentage people survive the impact of small rockfall events. However, official statistics on the vulnerability of people to rockfalls are lacking. Here, the vulnerability values are heuristically assigned based on the size of the rock block and the number of people in the group (Table 6). For risk calculation purposes (loss of life), the assigned vulnerability is multiplied by the number of people to obtain the number of victims. Thus, a vulnerability value of 0.4 for the impact on a group of 10 people, implies 4 deaths.

\begin{tabular}{|c|c|c|c|c|}
\hline \multirow{2}{*}{$\begin{array}{l}\text { Rockfall } \\
\text { volume }\left(\mathrm{m}^{3}\right)\end{array}$} & \multicolumn{4}{|l|}{ \# persons } \\
\cline { 2 - 5 } & individuals & Groups of 2 & Groups of 4 & Groups of 10 \\
\hline$<0.05$ & 0.5 & 0.3 & 0.1 & 0.05 \\
\hline $0.05<\mathrm{x}<0.5$ & 0.9 & 0.6 & 0.3 & 0.2 \\
\hline $0.5<\mathrm{x}<5$ & 1.0 & 0.9 & 0.6 & 0.4 \\
\hline $5<\mathrm{x}<50$ & 1.0 & 1.0 & 0.8 & 0.8 \\
\hline $50<\mathrm{x}<500$ & 1.0 & 1.0 & 1.0 & 1.0 \\
\hline$>500$ & 1.0 & 1.0 & 1.0 & 1.0 \\
\hline
\end{tabular}

Table 6. Estimated vulnerability values for different rockfall sizes and groups of visitors.

The risk is calculated for each of the six rockfall magnitude classes. Each one is characterized by its probability of occurrence, runout, impact probability and vulnerability

\section{Results}

The results are summarized in tables 7 to 11 . The two following scenarios are analyzed: 
Corresponds to the initial situation, without the presence of flexible rockfall protection fences, for unfragmented rockfall masses and for fragmental rockfalls and for an uniformly distributed flow of visitors (table 7) and for a segregated flow of visitors (table 8 and 9)

\section{Trail Section 1 length: $\underline{194,8 m}$}

\begin{tabular}{|l|l|l|l|l|l|l|l|l|}
\hline \multicolumn{2}{|l|}{} & \multicolumn{2}{c|}{ U } & \multicolumn{2}{c|}{ F } & & U & \multicolumn{1}{c|}{ F } \\
\hline Class $\mathrm{M}_{\mathrm{i}}\left(\mathrm{m}^{3}\right)$ & $\mathrm{Ni}$ & $\mathrm{P}(\mathrm{X}: \mathrm{D})$ & $\mathrm{P}(\mathrm{T}: \mathrm{X})$ & $\mathrm{P}(\mathrm{X}: \mathrm{D})$ & $\mathrm{P}(\mathrm{T}: \mathrm{X})$ & $\mathrm{V}$ & Risk & Risk \\
\hline$<0.05$ & 16.32 & 0.119 & 0.010 & 0.000 & 0.000 & 0.5 & $9.9 \times 10^{-3}$ & 0.000 \\
\hline $0.05<\mathrm{x}<0.5$ & 0.25 & 0.328 & 0.019 & 0.000 & 0.000 & 0.9 & $1.4 \times 10^{-3}$ & 0.000 \\
\hline $0.5<\mathrm{x}<5$ & $3.3 \times 10^{-2}$ & 0.590 & 0.022 & 0.043 & 0.034 & 1.0 & $4.3 \times 10^{-4}$ & $4.7 \times 10^{-5}$ \\
\hline $5<\mathrm{x}<50$ & $4.3 \times 10^{-3}$ & 0.765 & 0.066 & 0.233 & 0.120 & 1.0 & $2.2 \times 10^{-4}$ & $1.2 \times 10^{-4}$ \\
\hline $50<\mathrm{x}<500$ & $5.7 \times 10^{-4}$ & 0.832 & 0.124 & 0.631 & 0.374 & 1.0 & $5.9 \times 10^{-5}$ & $1.4 \times 10^{-4}$ \\
\hline$>500$ & $8.0 \times 10^{-5}$ & 0.874 & 0.153 & 0.800 & 0.678 & 1.0 & $1.0 \times 10^{-5}$ & $4.2 \times 10^{-5}$ \\
\hline Annual probability of loss of life
\end{tabular}

\section{Trail Section 2 length: $143.9 \mathrm{~m}$}

\begin{tabular}{|c|c|c|c|c|c|c|c|c|}
\hline Class $\mathrm{M}_{\mathrm{i}}\left(\mathrm{m}^{3}\right)$ & $\mathrm{Ni}$ & $\mathrm{P}(\mathrm{X}: \mathrm{D})$ & $\mathrm{P}(\mathrm{T}: \mathrm{X})$ & $\mathrm{P}(\mathrm{X}: \mathrm{D})$ & $\mathrm{P}(\mathrm{T}: \mathrm{X})$ & $\mathrm{V}$ & Risk & Risk \\
\hline$<0.05$ & 7.324 & 0.611 & 0.010 & 0.2940 & 0.0401 & 0.5 & $2.3 \times 10^{-2}$ & $4.4 \times 10^{-2}$ \\
\hline $0.05<x<0.5$ & 0.112 & 0.839 & 0.019 & 0.5700 & 0.062 & 0.9 & $1.6 \times 10^{-3}$ & $3.6 \times 10^{-3}$ \\
\hline $0.5<x<5$ & 0.015 & 0.945 & 0.022 & 0.7908 & 0.156 & 1.0 & $3.1 \times 10^{-4}$ & $1.8 \times 10^{-3}$ \\
\hline $5<x<50$ & $2.0 \times 10^{-3}$ & 0.970 & 0.066 & 0.9507 & 0.244 & 1.0 & $1.2 \times 10^{-4}$ & $4.5 \times 10^{-4}$ \\
\hline $50<x<500$ & $2.6 \times 10^{-4}$ & 0.979 & 0.124 & 0.9886 & 0.367 & 1.0 & $3.1 \times 10^{-5}$ & $9.4 \times 10^{-5}$ \\
\hline$>500$ & $3.0 \times 10^{-5}$ & 0.982 & 0.153 & 0.9917 & 0.472 & 1.0 & $5.0 \times 10^{-6}$ & $1.6 \times 10^{-5}$ \\
\hline \multicolumn{7}{|c|}{ Annual probability of loss of life } & 0.025 & 0.050 \\
\hline
\end{tabular}

Table 7. Individual risk (annual probability of loss of life) for unfragmented (U) and fragmental (F) rockfalls at the trail section 1 (top) and 2 (bottom). A uniformly distributed flow of visitors (700 visitors/day) is considered 


\begin{tabular}{|c|c|c|c|c|c|c|c|c|c|}
\hline \multirow{2}{*}{$\begin{array}{c}\text { Trail } 1 \\
\mathbf{M}_{\mathbf{i}}\left(\mathbf{m}^{3}\right)\end{array}$} & \multirow{2}{*}{$\begin{array}{c}\text { Events/y } \\
\text { r } \\
\mathbf{N i}\end{array}$} & \multicolumn{2}{|c|}{$\mathbf{U}$} & \multicolumn{2}{|c|}{$\mathbf{F}$} & \multirow[b]{2}{*}{$\mathbf{V}$} & \multirow{2}{*}{$\begin{array}{c}\text { visitors } \\
\#\end{array}$} & \multirow{2}{*}{$\begin{array}{c}\mathbf{U} \\
\text { Risk }\end{array}$} & \multirow{2}{*}{$\begin{array}{c}\text { F } \\
\text { Risk }\end{array}$} \\
\hline & & $P(X: D)$ & $\mathbf{P}(\mathrm{T}: \mathrm{X})$ & $\mathbf{P}(\mathrm{X}: \mathrm{D})$ & $\mathbf{P}(\mathrm{T}: \mathrm{X})$ & & & & \\
\hline$<0.05$ & 16.32 & 0.119 & 0.010 & 0.000 & 0.000 & 0.5 & 1 & $1.0 \times 10^{-3}$ & 0.000 \\
\hline $0.05<\mathrm{x}<0.5$ & 0.25 & 0.328 & 0.019 & 0.000 & 0.000 & 0.9 & 1 & $1.4 \times 10^{-4}$ & 0.000 \\
\hline $0.5<x<5$ & $3.3 \times 10^{-2}$ & 0.590 & 0.022 & 0.043 & 0.003 & 1.0 & 1 & $4.3 \times 10^{-5}$ & $5.0 \times 10^{-6}$ \\
\hline $5<x<50$ & $4.3 \times 10^{-3}$ & 0.765 & 0.066 & 0.233 & 0.012 & 1.0 & 1 & $2.2 \times 10^{-5}$ & $1.2 \times 10^{-6}$ \\
\hline $50<x<500$ & $5.7 \times 10^{-4}$ & 0.832 & 0.124 & 0.631 & 0.037 & 1.0 & 1 & $6.0 \times 10^{-6}$ & $1.4 \times 10^{-5}$ \\
\hline$>500$ & $8.0 \times 10^{-5}$ & 0.874 & 0.153 & 0.800 & 0.068 & 1.0 & 1 & $1.0 \times 10^{-6}$ & $4.0 \times 10^{-6}$ \\
\hline \multicolumn{8}{|c|}{ individuals (10\% of visitors) } & $1.2 \times 10^{-3}$ & $3.5 \times 10^{-5}$ \\
\hline$<0.05$ & 16.32 & 0.119 & 0.004 & 0.000 & 0.000 & 0.3 & 2 & $4.6 \times 10^{-3}$ & 0.000 \\
\hline $0.05<\mathrm{x}<0.5$ & 0.25 & 0.328 & 0.006 & 0.000 & 0.000 & 0.6 & 2 & $5.8 \times 10^{-4}$ & 0.000 \\
\hline $0.5<x<5$ & $3.3 \times 10^{-2}$ & 0.590 & 0.007 & 0.043 & 0.009 & 0.9 & 2 & $2.3 \times 10^{-4}$ & $2.3 \times 10^{-5}$ \\
\hline $5<x<50$ & $4.3 \times 10^{-3}$ & 0.765 & 0.015 & 0.233 & 0.029 & 1.0 & 2 & $1.0 \times 10^{-4}$ & $5.8 \times 10^{-5}$ \\
\hline $50<x<500$ & $5.7 \times 10^{-4}$ & 0.832 & 0.029 & 0.631 & 0.086 & 1.0 & 2 & $2.8 \times 10^{-5}$ & $6.2 \times 10^{-5}$ \\
\hline$>500$ & $8.0 \times 10^{-5}$ & 0.874 & 0.036 & 0.800 & 0.154 & 1.0 & 2 & $5.0 \times 10^{-6}$ & $1.9 \times 10^{-5}$ \\
\hline \multicolumn{8}{|c|}{ Groups of 2 (45\% of visitors) } & $5.5 \times 10^{-3}$ & $1.6 \times 10^{-4}$ \\
\hline$<0.05$ & 16.32 & 0.119 & 0.002 & 0.000 & 0.000 & 0.1 & 4 & $1.7 \times 10^{-3}$ & 0.000 \\
\hline $0.05<x<0.5$ & 0.25 & 0.328 & 0.003 & 0.000 & 0.000 & 0.3 & 4 & $2.9 \times 10^{-4}$ & 0.000 \\
\hline $0.5<x<5$ & $3.3 \times 10^{-2}$ & 0.590 & 0.003 & 0.043 & 0.004 & 0.6 & 4 & $1.5 \times 10^{-4}$ & $1.4 \times 10^{-5}$ \\
\hline $5<x<50$ & $4.3 \times 10^{-3}$ & 0.765 & 0.007 & 0.233 & 0.012 & 0.8 & 4 & $7.4 \times 10^{-5}$ & $3.8 \times 10^{-5}$ \\
\hline $50<x<500$ & $5.7 \times 10^{-4}$ & 0.832 & 0.012 & 0.631 & 0.034 & 1.0 & 4 & $2.3 \times 10^{-5}$ & $4.9 \times 10^{-5}$ \\
\hline$>500$ & $8.0 \times 10^{-5}$ & 0.874 & 0.015 & 0.800 & 0.060 & 1.0 & 4 & $4.0 \times 10^{-6}$ & $1.5 \times 10^{-5}$ \\
\hline \multicolumn{8}{|c|}{ Groups of 4 (35\% of visitors) } & $2.2 \times 10^{-3}$ & $1.2 \times 10^{-4}$ \\
\hline$<0.05$ & 16.32 & 0.119 & $6.1 \times 10^{-4}$ & 0.000 & 0.000 & 0.05 & 10 & $6.0 \times 10^{-4}$ & 0.000 \\
\hline $0.05<x<0.5$ & 0.25 & 0.328 & $7.0 \times 10^{-4}$ & 0.000 & 0.000 & 0.2 & 10 & $1.2 \times 10^{-4}$ & 0.000 \\
\hline $0.5<x<5$ & $3.3 \times 10^{-2}$ & 0.590 & $7.3 \times 10^{-4}$ & 0.043 & 0.001 & 0.4 & 10 & $5.7 \times 10^{-5}$ & $5.0 \times 10^{-6}$ \\
\hline $5<x<50$ & $4.3 \times 10^{-3}$ & 0.765 & $1.2 \times 10^{-3}$ & 0.233 & 0.002 & 0.8 & 10 & $3.1 \times 10^{-5}$ & $1.4 \times 10^{-5}$ \\
\hline $50<x<500$ & $5.7 \times 10^{-4}$ & 0.832 & $1.8 \times 10^{-3}$ & 0.631 & 0.004 & 1.0 & 10 & $8.0 \times 10^{-6}$ & $1.5 \times 10^{-5}$ \\
\hline$>500$ & $8.0 \times 10^{-5}$ & 0.874 & $2.0 \times 10^{-3}$ & 0.800 & 0.007 & 1.0 & 10 & $1.0 \times 10^{-6}$ & $4.0 \times 10^{-6}$ \\
\hline \multicolumn{8}{|c|}{ Groups of 10 (10\% of visitors) } & $8.1 \times 10^{-4}$ & $3.8 \times 10^{-5}$ \\
\hline \multicolumn{8}{|l|}{ Overall risk } & $9.8 \times 10^{-3}$ & $3.5 \times 10^{-4}$ \\
\hline
\end{tabular}

Table 8. Risk, expressed as the annual probability of loss of life, segregated by groups of visitors $(1,2,4$ and 10) for unfragmented $(U)$ and fragmental $(F)$ rockfall events at trail section 1. 


\begin{tabular}{|c|c|c|c|c|c|c|c|c|c|}
\hline \multirow{2}{*}{$\begin{array}{c}\text { Trail } 2 \\
\mathbf{M}_{\mathbf{i}}\left(\mathbf{m}^{3}\right)\end{array}$} & \multirow{2}{*}{$\begin{array}{c}\text { Events/y } \\
\text { r } \\
\mathbf{N i}\end{array}$} & \multicolumn{2}{|c|}{$\mathbf{U}$} & \multicolumn{2}{|c|}{$\mathbf{F}$} & \multirow[b]{2}{*}{$\mathbf{V}$} & \multirow{2}{*}{$\begin{array}{c}\text { visitors } \\
\# \\
\#\end{array}$} & \multirow{2}{*}{$\begin{array}{c}\mathbf{U} \\
\text { Risk }\end{array}$} & \multirow{2}{*}{$\begin{array}{c}\text { F } \\
\text { Risk }\end{array}$} \\
\hline & & $\mathbf{P}(\mathrm{X}: \mathrm{D})$ & $\mathbf{P ( T : X )}$ & $P(X: D)$ & $\mathbf{P}(\mathrm{T}: \mathrm{X})$ & & & & \\
\hline$<0.05$ & 7.32 & 0.611 & 0.001 & 0.294 & 0.004 & 0.5 & 1 & $2.3 \times 10^{-3}$ & $4.4 \times 10^{-3}$ \\
\hline $0.05<\mathrm{x}<0.5$ & 0.11 & 0.839 & 0.002 & 0.570 & 0.006 & 0.9 & 1 & $1.6 \times 10^{-4}$ & $3.6 \times 10^{-4}$ \\
\hline $0.5<x<5$ & $1.5 \times 10^{-2}$ & 0.945 & 0.002 & 0.791 & 0.016 & 1.0 & 1 & $3.1 \times 10^{-5}$ & $1.8 \times 10^{-4}$ \\
\hline $5<x<50$ & $2.0 \times 10^{-3}$ & 0.970 & 0.007 & 0.951 & 0.024 & 1.0 & 1 & $1.2 \times 10^{-5}$ & $4.5 \times 10^{-5}$ \\
\hline $50<x<500$ & $2.6 \times 10^{-4}$ & 0.979 & 0.012 & 0.989 & 0.037 & 1.0 & 1 & $3.0 \times 10^{-6}$ & $9.0 \times 10^{-6}$ \\
\hline$>500$ & $3.0 \times 10^{-5}$ & 0.982 & 0.015 & 0.992 & 0.047 & 1.0 & 1 & $1.0 \times 10^{-6}$ & $2.0 \times 10^{-6}$ \\
\hline \multicolumn{8}{|c|}{ Individuals (10\% of visitors) } & $2.5 \times 10^{-3}$ & $5.0 \times 10^{-3}$ \\
\hline$<0.05$ & 7.32 & 0.611 & $3.9 \times 10^{-3}$ & 0.294 & 0.011 & 0.3 & 2 & $1.1 \times 10^{-2}$ & $1.4 \times 10^{-2}$ \\
\hline $0.05<x<0.5$ & 0.11 & 0.839 & $5.9 \times 10^{-3}$ & 0.570 & 0.016 & 0.6 & 2 & $6.7 \times 10^{-4}$ & $1.2 \times 10^{-3}$ \\
\hline $0.5<x<5$ & $1.5 \times 10^{-2}$ & 0.945 & $6.5 \times 10^{-3}$ & 0.791 & 0.037 & 0.9 & 2 & $1.7 \times 10^{-4}$ & $7.7 \times 10^{-4}$ \\
\hline $5<x<50$ & $2.0 \times 10^{-3}$ & 0.970 & $1.6 \times 10^{-2}$ & 0.951 & 0.056 & 1.0 & 2 & $6.2 \times 10^{-5}$ & $2.1 \times 10^{-4}$ \\
\hline $50<x<500$ & $2.6 \times 10^{-4}$ & 0.979 & $2.9 \times 10^{-2}$ & 0.989 & 0.084 & 1.0 & 2 & $1.5 \times 10^{-5}$ & $4.3 \times 10^{-5}$ \\
\hline$>500$ & $3.0 \times 10^{-5}$ & 0.982 & $3.6 \times 10^{-2}$ & 0.992 & 0.108 & 1.0 & 2 & $2.0 \times 10^{-6}$ & $7.0 \times 10^{-6}$ \\
\hline \multicolumn{8}{|c|}{ Groups of 2 (45\% of visitors) } & 0.011 & 0.016 \\
\hline$<0.05$ & 7.32 & 0.611 & $2.2 \times 10^{-3}$ & 0.294 & 0.005 & 0.1 & 4 & $3.9 \times 10^{-3}$ & $4.1 \times 10^{-3}$ \\
\hline $0.05<x<0.5$ & 0.11 & 0.839 & $2.9 \times 10^{-3}$ & 0.570 & 0.007 & 0.3 & 4 & $3.3 \times 10^{-4}$ & $5.1 \times 10^{-4}$ \\
\hline $0.5<x<5$ & $1.5 \times 10^{-2}$ & 0.945 & $3.2 \times 10^{-3}$ & 0.791 & 0.015 & 0.6 & 4 & $1.1 \times 10^{-4}$ & $4.2 \times 10^{-4}$ \\
\hline $5<x<50$ & $2.0 \times 10^{-3}$ & 0.970 & $7.0 \times 10^{-3}$ & 0.951 & 0.023 & 0.8 & 4 & $4.2 \times 10^{-5}$ & $1.3 \times 10^{-4}$ \\
\hline $50<x<500$ & $2.6 \times 10^{-4}$ & 0.979 & $1.2 \times 10^{-2}$ & 0.989 & 0.033 & 1.0 & 4 & $1.2 \times 10^{-5}$ & $3.4 \times 10^{-5}$ \\
\hline$>500$ & $3.0 \times 10^{-5}$ & 0.982 & $1.5 \times 10^{-2}$ & 0.992 & 0.042 & 1.0 & 4 & $2.0 \times 10^{-6}$ & $6.0 \times 10^{-6}$ \\
\hline \multicolumn{8}{|c|}{ Groups of 4 (35\% of visitors) } & $4.4 \times 10^{-3}$ & $5.3 \times 10^{-3}$ \\
\hline$<0.05$ & 16.32 & 0.611 & $6.1 \times 10^{-4}$ & 0.294 & 0.001 & 0.05 & 10 & $1.4 \times 10^{-3}$ & $1.0 \times 10^{-3}$ \\
\hline $0.05<x<0.5$ & 7.32 & 0.839 & $7.0 \times 10^{-4}$ & 0.570 & 0.001 & 0.2 & 10 & $1.3 \times 10^{-4}$ & $1.5 \times 10^{-4}$ \\
\hline $0.5<x<5$ & 0.11 & 0.945 & $7.3 \times 10^{-4}$ & 0.791 & 0.002 & 0.4 & 10 & $4.1 \times 10^{-5}$ & $1.0 \times 10^{-4}$ \\
\hline $5<x<50$ & $1.5 \times 10^{-2}$ & 0.970 & $1.2 \times 10^{-3}$ & 0.951 & 0.003 & 0.8 & 10 & $1.8 \times 10^{-5}$ & $4.4 \times 10^{-5}$ \\
\hline $50<x<500$ & $2.0 \times 10^{-3}$ & 0.979 & $1.8 \times 10^{-3}$ & 0.989 & 0.004 & 1.0 & 10 & $4.0 \times 10^{-6}$ & $1.1 \times 10^{-5}$ \\
\hline$>500$ & $2.6 \times 10^{-4}$ & 0.982 & $2.0 \times 10^{-3}$ & 0.992 & 0.005 & 1.0 & 10 & $1.0 \times 10^{-6}$ & $2.0 \times 10^{-6}$ \\
\hline \multicolumn{8}{|c|}{ Groups of 10 (10\% of visitors) } & $1.6 \times 10^{-3}$ & $1.3 \times 10^{-3}$ \\
\hline \multicolumn{8}{|l|}{ Overall risk } & 0.020 & 0.028 \\
\hline
\end{tabular}


Some contrasting results of the rockfall fragmentation must be highlighted from

Table 7 and Table 8. In trail section 1, fragmentation reduces the risk totally for rockfall volumes of less than $0.5 \mathrm{~m}^{3}$. This is because fragmentation prevents the rock fragments from reaching the trail section that is, $\mathrm{P}(\mathrm{X}: \mathrm{D})=0$. On the opposite side, for rockfall volumes bigger than $50 \mathrm{~m}^{3}$, fragmentation raises the risk to the visitors. The reason is that the generation of the cone of fragments increases the exposure or the $\mathrm{P}(\mathrm{T}: \mathrm{X})$ value, particularly for large rockfall events whose fragments virtually occupy the whole $\mathrm{W}_{\mathrm{cx}}$. In contrast, for rockfall volumes ranging between 0.5 and $50 \mathrm{~m}^{3}$, the increase of exposure is either partially or fully compensated by the reduction of the runout.

As shown in Table 7 and discussed later in this section, the mentioned effects have a direct consequence on the overall risk value, as most of the risk originates from high-frequency small-magnitude rockfall events, the run-out of which is significantly shortened by fragmentation. Instead, the runout of large rockfall events $\left(>50 \mathrm{~m}^{3}\right)$ is less affected. $\mathrm{P}(\mathrm{X}: \mathrm{D})$ is reduced from 0.83 to 0.63 for rockfalls in the range of $50-500 \mathrm{~m}^{3}$ and from 0.87 to 0.80 for rockfalls over $500 \mathrm{~m}^{3}$. The annual probability of loss of life for a uniformly distributed flow of individual visitors is reduced from $1.2 \cdot 10^{-2}$ to $3.5 \cdot 10^{-4}$, which is almost two orders of magnitude. The segregation of the visitors flow in groups has only a minor influence on the results (Table 8). For unfragmented rockfalls the annual probability of loss of life is reduced from $1.21 \cdot 10^{-2}$ to $9.8 \cdot 10^{-3}$ while for fragmental rockfalls it remains virtually the same as $3.5 \cdot 10^{-4}$.

The analysis of trail section 2 (Table 7 and Table 9) shows that risk has increased for all the range of rockfall volumes, without exception. The trail 2 runs below a steep rock wall where few blocks stop along the trajectory. In this case, the slight reduction of the probability of reach $\mathrm{P}(\mathrm{X}: \mathrm{D})$ that fragmentation causes, does not compensate the higher exposure, and risk increases. For instance, for rockfall volumes ranging between 5 and $50 \mathrm{~m}^{3}$ (Table 7), the reduction of reach probability, which has passed from 0.97 to 0.95 , has been counterbalanced by a higher impact probability, from 0.06 to 0.24. The length of the slope above the trail section 2 is shorter than in the case of trail section 1 and, consequently, this affects the divergence of trajectories of the fragments and $\mathrm{W}_{\mathrm{cx}}$ is narrower. Despite the latter, the results of Table 9 for the segregated flow of visitors confirm that the probability of impact of the fragmental rockfalls has increased substantially, typically by a factor of 2 or 3. Quantitatively the increase of risk is mostly due to small rockfall events (volumes $<0.5 \mathrm{~m}^{3}$ ), which are the most frequent. 
The presence of flexible rockfall protection fences is analyzed for trail section 1 only. This is carried out for both the unfragmented and fragmental rockfalls, and for the continuous flow of visitors (Table 10) and the segregated flow of visitors (Table 11). The analysis addresses the performance of the rockfall fences in terms of their efficiency to intercept fragmental rockfalls but not their spatial arrangement, which is the existing one.

Section length: $\underline{194,8 \mathrm{~m}}$

\begin{tabular}{|c|c|c|c|c|c|}
\hline \multicolumn{5}{|c|}{ Unfragmented rockfalls } \\
\hline Class $\mathrm{M}_{\mathrm{i}}\left(\mathrm{m}^{3}\right)$ & $\mathrm{Ni}$ & $\mathrm{P}(\mathrm{X}: \mathrm{D})$ & $\mathrm{P}(\mathrm{T}: \mathrm{X})$ & $\mathrm{V}$ & Risk \\
\hline$<0.05$ & 16.31851 & 0.0220 & 0.010208 & 0.5 & 0.001832 \\
\hline $0.05<\mathrm{x}<0.5$ & 0.25049 & 0.0647 & 0.018958 & 0.9 & 0.000277 \\
\hline $0.5<\mathrm{x}<5$ & 0.03301 & 0.1455 & 0.021875 & 1.0 & 0.000105 \\
\hline $5<\mathrm{x}<50$ & 0.00434 & 0.7361 & 0.065625 & 1.0 & 0.000210 \\
\hline $50<\mathrm{x}<500$ & 0.00057 & 0.8312 & 0.123958 & 1.0 & 0.000059 \\
\hline$>500$ & 0.00008 & 0.8737 & 0.153125 & 1.0 & 0.000010 \\
\hline Annual probability of loss of life & \multicolumn{5}{|l|}{} \\
\hline \multicolumn{7}{|l|}{ Fragmental rockfalls } & 0.00249 \\
\hline$<0.05$ & 16.31851 & 0.0000 & 0.0000 & 0.5 & 0.000000 \\
\hline $0.05<\mathrm{x}<0.5$ & 0.25049 & 0.0000 & 0.0000 & 0.9 & 0.000000 \\
\hline $0.5<\mathrm{x}<5$ & 0.03301 & 0.0122 & 0.0370 & 1.0 & 0.000015 \\
\hline $5<\mathrm{x}<50$ & 0.00434 & 0.1310 & 0.1216 & 1.0 & 0.000069 \\
\hline $50<\mathrm{x}<500$ & 0.00057 & 0.5135 & 0.3590 & 1.0 & 0.000106 \\
\hline$>500$ & 0.00008 & 0.7574 & 0.6504 & 1.0 & 0.000038 \\
\hline Annual probability of loss of life
\end{tabular}
rockfalls considering the presence of flexible rockfall protection fences. Uniformly distributed flow of 


\begin{tabular}{|c|c|c|c|c|c|c|c|c|c|}
\hline \multirow{2}{*}{$\begin{array}{c}\text { Trail } 1 \\
\mathbf{M}_{\mathbf{i}}\left(\mathbf{m}^{3}\right)\end{array}$} & \multirow{2}{*}{$\begin{array}{c}\text { Events/y } \\
\text { r } \\
\mathbf{N i}\end{array}$} & \multicolumn{2}{|c|}{$\mathbf{U}$} & \multicolumn{2}{|c|}{$\mathbf{F}$} & \multirow[b]{2}{*}{$\mathbf{V}$} & \multirow{2}{*}{$\begin{array}{c}\text { visitors } \\
\#\end{array}$} & \multirow{2}{*}{$\begin{array}{c}\mathbf{U} \\
\text { Risk }\end{array}$} & \multirow{2}{*}{$\begin{array}{c}\text { F } \\
\text { Risk }\end{array}$} \\
\hline & & $\mathbf{P}(\mathrm{X}: \mathrm{D})$ & $\mathbf{P ( T : X )}$ & P(X:D) & $\mathbf{P}(\mathrm{T}: \mathrm{X})$ & & & & \\
\hline$<0.05$ & 16.32 & 0.022 & $1.0 \times 10^{-3}$ & 0.000 & 0.000 & 0.5 & 1 & $1.8 \times 10^{-4}$ & 0.000 \\
\hline $0.05<x<0.5$ & 0.25 & 0.065 & $1.9 \times 10^{-3}$ & 0.000 & 0.000 & 0.9 & 1 & $2.8 \times 10^{-5}$ & 0.000 \\
\hline $0.5<x<5$ & $3.3 \times 10^{-2}$ & 0.146 & $2.2 \times 10^{-3}$ & 0.012 & 0.004 & 1.0 & 1 & $1.1 \times 10^{-5}$ & $1.5 \times 10^{-6}$ \\
\hline $5<x<50$ & $4.3 \times 10^{-3}$ & 0.736 & $6.6 \times 10^{-3}$ & 0.131 & 0.012 & 1.0 & 1 & $2.1 \times 10^{-5}$ & $6.9 \times 10^{-6}$ \\
\hline $50<x<500$ & $5.7 \times 10^{-4}$ & 0.831 & $1.2 \times 10^{-2}$ & 0.514 & 0.036 & 1.0 & 1 & $6.0 \times 10^{-6}$ & $1.1 \times 10^{-5}$ \\
\hline$>500$ & $8.0 \times 10^{-5}$ & 0.874 & $1.5 \times 10^{-2}$ & 0.757 & 0.066 & 1.0 & 1 & $1.0 \times 10^{-6}$ & $3.8 \times 10^{-6}$ \\
\hline \multicolumn{8}{|c|}{ Individuals (10\% of visitors) } & $2.5 \times 10^{-4}$ & $2.3 \times 10^{-5}$ \\
\hline$<0.05$ & 16.32 & 0.022 & $3.9 \times 10^{-3}$ & 0.000 & 0.000 & 0.3 & 2 & $8.5 \times 10^{-4}$ & 0.000 \\
\hline $0.05<x<0.5$ & 0.25 & 0.065 & $5.9 \times 10^{-3}$ & 0.000 & 0.000 & 0.6 & 2 & $1.1 \times 10^{-4}$ & 0.000 \\
\hline $0.5<x<5$ & $3.3 \times 10^{-2}$ & 0.146 & $6.5 \times 10^{-3}$ & 0.012 & 0.010 & 0.9 & 2 & $5.7 \times 10^{-5}$ & $7.0 \times 10^{-6}$ \\
\hline $5<x<50$ & $4.3 \times 10^{-3}$ & 0.736 & $1.5 \times 10^{-2}$ & 0.131 & 0.029 & 1.0 & 2 & $9.4 \times 10^{-5}$ & $3.3 \times 10^{-5}$ \\
\hline $50<x<500$ & $5.7 \times 10^{-4}$ & 0.831 & $2.9 \times 10^{-2}$ & 0.514 & 0.082 & 1.0 & 2 & $2.8 \times 10^{-5}$ & $4.8 \times 10^{-5}$ \\
\hline$>500$ & $8.0 \times 10^{-5}$ & 0.874 & $3.6 \times 10^{-2}$ & 0.757 & 0.148 & 1.0 & 2 & $5.0 \times 10^{-6}$ & $1.7 \times 10^{-5}$ \\
\hline \multicolumn{8}{|c|}{ Groups of 2 ( $45 \%$ of visitors) } & $1.1 \times 10^{-3}$ & $1.1 \times 10^{-4}$ \\
\hline$<0.05$ & 16.32 & 0.022 & $2.2 \times 10^{-3}$ & 0.000 & 0.000 & 0.1 & 4 & $3.1 \times 10^{-4}$ & 0.000 \\
\hline $0.05<\mathrm{x}<0.5$ & 0.25 & 0.065 & $2.9 \times 10^{-3}$ & 0.000 & 0.000 & 0.3 & 4 & $5.7 \times 10^{-5}$ & 0.000 \\
\hline $0.5<x<5$ & $3.3 \times 10^{-2}$ & 0.146 & $3.2 \times 10^{-3}$ & 0.012 & 0.004 & 0.6 & 4 & $3.7 \times 10^{-5}$ & $4.0 \times 10^{-6}$ \\
\hline $5<x<50$ & $4.3 \times 10^{-3}$ & 0.736 & $6.7 \times 10^{-3}$ & 0.131 & 0.012 & 0.8 & 4 & $7.1 \times 10^{-5}$ & $2.2 \times 10^{-5}$ \\
\hline $50<x<500$ & $5.7 \times 10^{-4}$ & 0.831 & $1.2 \times 10^{-2}$ & 0.514 & 0.033 & 1.0 & 4 & $2.3 \times 10^{-5}$ & $3.8 \times 10^{-5}$ \\
\hline$>500$ & $8.0 \times 10^{-5}$ & 0.874 & $1.5 \times 10^{-2}$ & 0.757 & 0.058 & 1.0 & 4 & $4.0 \times 10^{-6}$ & $1.3 \times 10^{-5}$ \\
\hline \multicolumn{8}{|c|}{ Groups of 4 (35\% of visitors) } & $5.0 \times 10^{-4}$ & $7.8 \times 10^{-5}$ \\
\hline$<0.05$ & 16.32 & 0.022 & $6.1 \times 10^{-4}$ & 0.000 & 0.000 & 0.05 & 10 & $1.1 \times 10^{-4}$ & 0.000 \\
\hline $0.05<x<0.5$ & 0.25 & 0.065 & $7.0 \times 10^{-4}$ & 0.000 & 0.000 & 0.2 & 10 & $2.3 \times 10^{-5}$ & 0.000 \\
\hline $0.5<x<5$ & $3.3 \times 10^{-2}$ & 0.146 & $7.3 \times 10^{-4}$ & 0.012 & 0.001 & 0.4 & 10 & $1.4 \times 10^{-5}$ & $1.0 \times 10^{-6}$ \\
\hline $5<x<50$ & $4.3 \times 10^{-3}$ & 0.736 & $1.2 \times 10^{-3}$ & 0.131 & 0.002 & 0.8 & 10 & $3.0 \times 10^{-5}$ & $8.0 \times 10^{-6}$ \\
\hline $50<x<500$ & $5.7 \times 10^{-4}$ & 0.831 & $1.8 \times 10^{-3}$ & 0.514 & 0.004 & 1.0 & 10 & $8.0 \times 10^{-6}$ & $1.2 \times 10^{-5}$ \\
\hline$>500$ & $8.0 \times 10^{-5}$ & 0.874 & $2.0 \times 10^{-3}$ & 0.757 & 0.007 & 1.0 & 10 & $1.0 \times 10^{-6}$ & $4.0 \times 10^{-6}$ \\
\hline \multicolumn{8}{|c|}{ Groups of 10 (10\% of visitors) } & $1.9 \times 10^{-4}$ & $2.5 \times 10^{-5}$ \\
\hline \multicolumn{8}{|l|}{ Overall risk } & $2.1 \times 10^{-3}$ & $2.3 \times 10^{-4}$ \\
\hline
\end{tabular}

Table 11. Residual risk remaining after the construction of $1500 \mathrm{~kJ}$ rockfall fences, segregated by groups of visitors $(1,2,4$, and 10$)$ for unfragmented $(U)$ and fragmental $(F)$ rockfall events. 
In presence of rockfall protection fences, the fragmentation reduces the overall risk by one order of magnitude. The runout reduction and the increase of exposure caused by fragmentation as in natural conditions, are also found here. However, the efficacy of the flexible rockfall fences in halting the falling blocks and the subsequent risk reduction is better observed in the analysis of unfragmented rockfalls. There is a reduction of $80 \%$ of the annual risk for both the uniformly distributed flow of visitors and the segregated flow of visitors (from 0.012 to 0.0025 and from 0.0098 to 0.0021 , respectively). Most of the reduction is due to the trapping of small-size rockfall events. The reduction of risk for fragmental rockfall is less significant. The annual risk is reduced to around 35\% for both the uniformly distributed flow of visitors and the segregated flow of visitors (from 0.00035 to 0.00023 ). The reason is that most of the mid and large-size fragmental rockfalls cannot be stopped by the fences. There exists however an additional cause for this particular example. The probability of reach $\mathrm{P}(\mathrm{X}: \mathrm{D})$ for fragmental rockfalls in the volume range of 0.5 to $5 \mathrm{~m}^{3}$, has been reduced only from 0.04 to 0.01 . This contrast with the significant reduction observed for the unfragmented events which is from 0.59 to 0.15 . The explanation for such behavior is found in Figure 9, bottom right. A small percentage of modelled trajectories are not intercepted by the fences while some rebounds are higher than the height of the fences. This percentage cannot be reduced unless further protection work is carried out.

A significant percentage (over 50\%) of the large rockfalls for both unfragmented and fragmental rockfalls reach the trail despite the presence of fences. In most of the cases, the kinetic energy of the blocks is too high for the existing $1500 \mathrm{~kJ}$ protection fences, which are not capable of withstanding the impact. It is worth noticing however that despite this restriction, for the range of fragmental rockfall volumes between 5 and $50 \mathrm{~m}^{3}$, the reach probability is substantially reduced, from 0.74 to 0.13 .

\section{Discussion}

In the example of Monasterio de Piedra, we worked with a high-resolution DEM (0.2x0.2m) generated from digital images captured by a drone. There are, however, several sources of uncertainty in all the steps followed. Because of this, the example we provide is not aimed at yielding a precise value of risk but to discuss how fragmentation affects both risk and the interpretation of the results.

The first source of uncertainty is the frequency-magnitude relation, which has been prepared using a 15yr record of rock blocks trapped in the existing fences. It is assumed that each block corresponds to one independent event obviating the fact that several of the retained blocks might be fragments belonging to the same rockfall event. This assumption underestimates the magnitude of the events (all the blocks 
trapped are less than $1 \mathrm{~m}^{3}$ ). Conversely, rock blocks located upslope of the flexible fences were not counted because their age cannot be constrained, which underestimates their frequency.

Another source of uncertainty are the rockfall release points. All the detachment points are assumed homogeneously distributed along the crest line of the cliffs. Although this hypothesis fits well for large rockfall volumes, it is clearly conservative for both small and mid-size events (up to $50 \mathrm{~m}^{3}$ ) since a percentage of them originates in middle and lower sectors of the cliff face and, therefore, they develop lower kinetic energies and runout. Furthermore, despite the RockGIS model has been calibrated with the rockfall event of 2017 and with the back analysis of the blocks released during scaling works in 2015, the model is based on a lumped mass approach whose restrictions are already known. The roughness is included in the restitution factors and is assumed constant for the whole slope. Finally, the exposure considers a debris front width $\left(\mathrm{W}_{\mathrm{r}}\right)$ calculated based on the modal rock block size $\left(\mathrm{W}_{\mathrm{mx}}\right)$ rather than the actual size distribution of the blocks reaching the analyzed section.

All these uncertainties and limitations of the approach do not alter the fact that fragmentation modifies strongly the results of the risk analysis. However, its effects are not obvious and must be evaluated at each location or analyzed section. The main reason is that both the reach probability and the exposure are spatially dependent.

A contrasting effect on the resulting risk is observed in the two trail sections analyzed. The risk in trail section 1 is significantly reduced by fragmentation. The greater length of the propagation slope favors successive impacts and dissipation of energy (Figure 9). The smaller size of the newly generated fragments travel shorter distances. As the volume of the rock fall increases, so does the size of the blocks, the divergence of the trajectories (Wcx), and the exposure $\mathrm{P}(\mathrm{T} \mid \mathrm{X})$, thereby partially compensating the reduction of the runout. The analysis of trail section 2 of Table 11 provides a different perspective because due to the steepness of the slope, most of the new fragments generated are able to reach the section of analysis. In this case, the beneficial effect of the fragmentation on the runout is lost.

The design of remedial measures is beyond the scope of this paper. However, the scenario analyzed with flexible rockfall fences gives some hints of their performance. The simulations show that the efficacy of the fences for mid-size events increases with fragmentation. After the impact, the velocity of the broken mass is transferred to the smaller rock fragments, whose energies are substantially reduced. In that respect, fragmentation improves the efficiency of the protection system. In the example of trail section 1, the existing barriers intercept virtually all (98.8\%) the fragments generated by the 0.5 to $5 \mathrm{~m}^{3}$ rockfall events, and a high percentage (87\%) of the fragments generated by the 5 to $50 \mathrm{~m}^{3}$ rockfall events, which are the most frequent events in the site (up to 100yr return period). The analysis also shows that a few 
trajectories may avoid the barriers by either passing between them or by bouncing over them. It is important noticing that the proper interpretation of the performance of the rockfall fences must take into account the various assumptions of our analysis. First and most importantly, the analysis does not account for the multiple block impacts. Furthermore, no damage function is applied to the fences. In the simulations, all impacts with kinetic energies below $1500 \mathrm{~kJ}$ are trapped without affecting the future performance of the fence. This is an arguable assumption as the performance of the rockfall fences is more complex. The efficiency of the fence may decrease below the maximum impact load (Duffy and Badger, 2012; Volkwein et al. 2011) while small blocks with kinetic energy lower than the design values, may puncture the fence panel by the bullet effect (Spadari et al. 2012). As consequence, our evaluation most likely overestimates the efficiency of the existing barriers.

\section{Conclusions}

The quantitative risk analysis of fragmental rockfall has to overcome several challenges related to the evaluation of the occurrence probability or frequency of the events, the runout modelling and the behavior of the falling mass. It must also account for the uncertainties due to inherently complex physical processes involved and the stochastic variability of all the relevant parameters. To the authors knowledge, this is the first attempt to address the QRA of fragmental rockfalls. It has been carried out with simulations using the RockGIS code and considering a fragmentation law for the falling rock masses. Despite all the limitations, the example we present highlights the relevance of fragmentation.

One of the most important effects of fragmentation is on the rockfall runout. Fragmentation may significantly reduce the rockfall propagation if the slope is sufficiently gentle and long. This is clearly illustrated in the analysis of trail section 1 in the Monasterio de Piedra. None of the rock fragments of the small size $\left(<0.5 \mathrm{~m}^{3}\right)$ fragmented rock masses reaches the trail section. This is the reason for the substantial reduction (more than one order of magnitude) compared to the value of risk for intact blocks for this magnitude range. However, the favorable effect of fragmentation disappears when rockfalls propagate along steep slopes. The blocks cannot stop and the generated cone of fragments increases the exposure, as shown in the analysis of trail section 2.

Considering fragmentation in the risk analysis forces the redefinition of the reach probability $\mathrm{P}(\mathrm{X} \mid \mathrm{D})$ because a paradoxical situation may appear if a number of block fragments bigger than the number of initiators attain the distance of the analyzed section. In addition, our analysis has required a new procedure to quantify the exposure. The fragmentation due to the impact of small to mid-size rock masses (e.g. $<100 \mathrm{~m}^{3}$ ) on the ground, generates divergent trajectories of the new fragments, which define a cone. The projected width of the cone on the ground surface determines the length of the trail section 
affected by the arrival of rock fragments $\left(\mathrm{W}_{\mathrm{cx}}\right)$. The procedure followed includes the calculation of the number of fragments that reach the section and the proportion of the debris front width (Wr) that they occupy. An important effect of fragmentation is that the exposure $\mathrm{P}(\mathrm{T}: \mathrm{X})$ is spatially dependent, as shown by the variability of the width of the cone of fragments.

In the example of Monasterio de Piedra, the fragmentation of rockfall larger than $50 \mathrm{~m}^{3}$ increases notably the exposure or the impact probability. In the case of trail section 1 , the increase is counterbalanced by the reduction of the runout. The results show that the value of risk associated to both unfragmented and fragmental rockfalls is similar but the contribution of factors is different. This fact has to be taken into account in order not to reach misleading conclusions.

The performance of the existing protection flexible fences has also been discussed. The efficacy of rockfall fences for rockfall events up to $50 \mathrm{~m}^{3}$ increases with fragmentation. However, additional work is needed on the performance of these structures before the efficiency and the residual risk can be evaluated reliably.

In summary, fragmentation has both a significant and contrasting effect on the calculation of risk and it should not be obviated in risk analysis. Risk is significantly reduced if the slope where blocks propagate is sufficiently long and gentle. In this case, the new fragments generated mobilize less energy and can be trapped by the topographic irregularities, obstacles and the protection measures. Conversely, a wide range of block sizes are able to reach the trails running below steep slopes. In such a situation, fragmentation increases notably the divergence of the block trajectories, which increases the exposure on visitors. Our simulations also show that the segregation of the visitors' flow has only a minor influence in the results of the risk analysis.

\section{Acknowledgements}

This work has been carried out with the support of the fellowship to the last two authors and within the framework of the research project Rockmodels financed by the Spanish Ministry of Economy and Competitiveness and the European Regional Development's funds (FEDER), (BIA2016- 75668-P, AEI/FEDER, UE) and by the grants to the second and third authors (BES-2014-069795 and FPU13/04252, respectively). We also appreciate all the facilities provided by Monasterio de Piedra S.A. to carry out this work. We would like to thank the helpful comments of the anonymous reviewers. 


\section{References}

612

Agliardi F, Crosta GB (2003) High resolution three-dimensional numerical modelling of rockfalls. International Journal of Rock Mechanics and Mining Sciences 40: 455-471

Agliardi F, Crosta GB, Frattini P (2009) Integrating rockfall risk assessment and countermeasure design by 3D modelling techniques. Nat Hazards Earth Syst Sci 9:1059-1073

Arenas C, Vázquez-Urbez M, Auqué L, Sancho C, Osácar C, Pardo G (2014) Intrinsic and extrinsic controls of spatial and temporal variations in modern fluvial tufa sedimentation: A thirteen-year record from a semi-arid environment. Sedimentology 61: 90-132

Asteriou P, Saroglou H, Tsiambaos (2012) Geotechnical and kinematic parameters affecting the coefficients of restitution for rock fall analysis. International Journal of Rock Mechanics \& Mining Sciences 54: 103-113

Bourrier F, Hungr O (2011) Rockfall dynamics: a critical review of collision and rebound models. In: Lambert S, Nicot F (ed) Rockfall Engineering, ISTE Ltd- John Wiley and Sons, Inc., Hoboken, 175-209

Bourrier F, Dorren L, Nicot F, Berger F, Darve F (2009) Toward objective rockfall trajectory simulation using a stochastic impact model. Geomorphology, 110: 68-79

Bourrier F, Berger F, Tardif P, Dorren L, Hungr O (2012) Rockfall rebound: comparison of detailed field experiments and alternative modelling approaches. Earth Surface Processes and Landforms, 37: 656-665

Bunce CM, Cruden D M, Morgenstern N R (1997) Assessment of the hazard from rock fall on a highway, Can. Geotech. J 34: 344-356

Chau KT, Wong RCH, Liu J, Lee CF (2003) Rockfall Hazard Analysis for Hong Kong Based on Rockfall Inventory. Rock Mech Rock Eng 36: 383-408

Corominas J, Mavrouli O, Santana D, Moya J (2012) Simplified approach for obtaining the block volume distribution of fragmental rockfalls. E Eberhardt, C Froese, A K Turner \& S Leroueil (editors). Landslides and engineered slopes. Taylor and Francis. Vol 2: 1159-1164

Corominas J, van Westen C, Frattini P, Cascini L, Malet JP, Fotopoulou S, Catani F, Van Den Eeckhaut M, Mavrouli O, Agliardi F, Pitilakis K, Winter MG, Pastor M, Ferlisi S, Tofani V, Hervás J, Smith JT (2014) Recommendations for the quantitative analysis of landslide risk. Bull Eng Geology Environment, 73: 209-263

Corona C, Lopez-Saez J, Favillier A, Mainieri R, Eckert N, Trappmann D, Stoffel M, Bourrier F, Berger F (2017) Modeling rockfall frequency and bounce height from three-dimensional simulation process models and growth disturbances in submontane broadleaved trees. Geomorphology 281: 66-77

Crosta GB, Agliardi F (2004) Parametric evaluation of 3D dispersion of rockfall trajectories. Nat Hazards Earth Syst Sci 4:583-598

Davies TR, McSaveney MJ (2002) Dynamic simulation of the motion of fragmenting rock avalanches. Canadian Geotechical Journal 39:789-798

Dorren LKA (2012) Rockyfor3D (v5.1) revealed—transparent description of the complete 3D rockfall model. http://www.ecorisq.org/ 
Dorren, LKA, Berger F, Putters US (2006). Real-size experiments and 3-D simulation of rockfall on forested and non-forested slopes. Nat Hazards Earth Syst Sci, 6: 145-153

Dorren L, Domaas U, Kronholm K, Labiouse V (2011). Methods for predicting rockfall trajectories and run-out zones. In: Rockfall Engineering, edited by: Lambert, S. and Nicot, F., ISTE Ltd- John Wiley and Sons, Inc., Hoboken, 143-173

Duffy JD, Badger TC (2012). Flexible rockfall fences. In Turner and Schuster (Eds). Rockfall characterization and control. Transportation Research Board, Washington D.C. pp. 526-563

Evans S, Hungr O (1993). The assessment of rockfall hazard at the base of talus slopes. Canadian Geotechnical Journal 30: 620-636

Fell R, Corominas J, Bonnard Ch, Cascini L, Leroi E, Savage WZ on behalf of the JTC-1 Joint Technical Committee on Landslides and Engineered Slopes (2008) Guidelines for landslide susceptibility, hazard and risk zoning for land use planning. Engineering Geology 102: 85-98

Ferlisi S, Cascini L, Corominas J, Matano F (2012) Rockfall risk assessment to persons travelling in vehicles along a road: the case study of the Amalfi coastal road (southern Italy). Nat Hazards 62:691-721

Frattini P, Crosta GB, Agliardi F, Imposimato S (2013) Challenging Calibration in 3D Rockfall Modelling. In: Margottini C, Canuti P, Sassa K. (ed) Landslide Science and Practice. Springer, Berlin, Heidelberg. pp. 169-175 Giani GP, Giacomini A, Migliazza M, Segalini A (2004) Experimental and Theoretical Studies to Improve Rock Fall Analysis and Protection Work Design. Rock Mechanics and Rock Engineering 37: 369-389.

Gischig V, Hungr O, Mitchell A, Bourrier F (2015) Pierre3D - a 3D stochastic rock fall simulator based on random ground roughness and hyperbolic restitution factors. Canadian Geotechnical Journal 52: 1360-1373

Gutierrez Elorza M, Sesé Martínez VH (2001) Multiple talus flatirons, variations of scarp retreat rates and the evolution of slopes in Almazán Basin (semi-arid central Spain). Geomorphology 38: 19-29.

Guzzetti F, Crosta, GB, Detti R, Agliardi F (2002) STONE: A computer program for the three-dimensional simulation of rock-falls. Computers \& Geosciences, 28: 1079-1093.

Guzzetti F, Reichenbach, P, Ghigi S (2004) Rockfall hazard and risk assessment along a transportation corridor in the Nera Valley, central Italy. Environmental Management, 34 : 191-208

Hantz D (2011) Quantitative assessment of diffuse rock fall hazard along a cliff foot, Nat. Hazards Earth Syst. Sci., 11, 1303-1309

Hoek E, Bray JW (1988). Rock slope Engineering. Institution of Mining and Metallurgy. 357 pp.

Hungr O, Evans SG, Hazzard J (1999) Magnitude and frequency of rock falls and rock slides along the main transportation corridors of southwestern British Columbia. Canadian Geotechnical Journal, 36: 224-238

Jaboyedoff M, Baillifard F, Philippossian F, Rouiller JD (2004) Assessing fracture occurrence using weighted fracturing density a step towards estimating rock instability hazard. Nat. Hazards Earth Syst. Sci., 4: 83-93

Jaboyedoff M., Labiouse V. (2011) Technical Note: Preliminary estimation of rockfall runout zones. Nat Hazards and Earth System Science, 11: 819-828.

Jaboyedoff M, Dudt JP, Labiouse V (2005) An attempt to refine rockfall hazard zoning based on the kinetic energy, frequency and fragmentation degree, Nat. Hazards Earth Syst. Sci., 5, 621-632 
Lambert S, Bourrier F, Toe D(2013) Improving three-dimensional rockfall trajectory simulation codes for assessing the efficiency of protective embankments. International Journal of Rock Mechanics \& Mining Sciences, 60: 26-36

Lan H, Martin CD, Zhou CH, Lim CH (2010). Rockfall hazard analysis using LiDAR and spatial modeling. Geomorphology, 118: 213-223

Loye A, Jaboyedoff M, Pedrazzini A (2009) Identification of potential rockfall source areas at a regional scale using a DEM-based geomorphometric analysis. Nat. Hazards Earth Syst. Sci., 9: 1643-1653

Macciotta R, Martin CD, Cruden DM (2015) Probabilistic estimation of rockfall height and kinetic energy based on a three-dimensional trajectory model and Monte Carlo simulation. Landslides 15: 757-772

Macciotta R, Martin CD, Morgenstern NR, Cruden D.M (2016) Quantitative risk assessment of slope hazards along a section of railway in the Canadian Cordillera - a methodology considering the uncertainty in the results, Landslides, 13: 15-117

Matas G, Lantada N, Corominas J, Gili JA, Ruiz-Carulla R, Prades A. (2017). RockGIS: a GIS-based model for the analysis of fragmentation in rockfalls. Landslides, 14: 1565-1578

Michoud C, Derron MH, Horton, P, Jaboyedoff M, Baillifard FJ, Loye A, Nicolet P, Pedrazzini A, Queyrel A. (2012) Rockfall hazard and risk assessments along roads at a regional scale: example in Swiss Alps, Nat. Hazards Earth Syst. Sci., 12, 615-629

Nicolet P, Jaboyedoff M, Cloutier C, Crosta G, Lévy S. (2016) Brief Communication: On direct impact probability of landslides on vehicles. Nat. Hazards Earth Syst. Sci., 16, 995-1004

Osácar MC, Arenas C, Vázquez-Urbez M, Sancho C, Auqué LF, Pardo G (2013) Environmental factors controlling the $\delta^{13} \mathrm{C}$ and $\delta^{18} \mathrm{O}$ variatins of recent fluvial tufas: a 12-year record from the Monasterio de Piedra Natural Park (NE Iberian Peninsula). Journal of Sedimentary Research 83: 309-322

Preh A, Mitchell A, Hungr O, Kolenprat B. (2015) Stochastic analysis of rockfall dynamics in quarry slopes. Int J Rock Mech Min Sciences 80: 57-66.

Roberds W (2005) Estimating temporal and spatial variability and vulnerability. In Landslide Risk Management, Editors O Hungr, R Fell, R Couture and E Eberhardt, Taylor and Francis, London, pp 129-158

Ruiz-Carulla R, Corominas J, Mavrouli O (2015) A Methodology to Obtain the Block Size Distribution of Fragmental Rockfall Deposits. Landslides 12: 815-25.

Ruiz-Carulla R., Corominas J, Mavrouli O (2017) A fractal fragmentation model for rockfalls. Landslides 14: 875-889

Sancho C, Gutiérrez M, Peña JL, Burillo F. (1988) A quantitative approach to scarp retreat starting from triangular slope facets, central Ebro Basin, Spain. Catena Suppl 13: 139-146

Spadari M, Giacomini A, Buzzi O, Hambleton JP (2012) Prediction of the Bullet Effect for Rockfall Barriers: a Scaling Approach. Rock Mech Rock Eng 45: 131-144

Stoffel M, Wehrli A, Kühne R, Dorren LKA, Perret S, Kienholz H (2006) Assessing the protective effect of mountain forests against rockfall using a 3D simulation model. Forest Ecology and Management 225: 113-122

Straub D, Schubert M (2008) Modeling and managing uncertainties in rock-fall hazards. Georisk, 2: 1-15 
720 Turner AK, Jayaprakash GP (2012) Introduction. In Turner AK, Schuster RL (ed). Rockfall characterization and

721 control. Transportation Research Board, National Academy of Sciences. Whasington D.C. pp. 3-20

722 Volkwein A, Schellenberg K, Labiouse V, Agliardi F, Berger F, Bourrier F, Dorren LKA, Gerber W, Jaboyedoff

723 M (2011) Rockfall characterisation and structural protection—a review. Nat Hazards Earth Syst 11:2617-2651

724 Wyllie DC (2014) Calibration of rock fall modeling parameters. Int J Rock Mech Min Sci 67:170-180 